\title{
Review of trap-and-haul for managing Pacific salmonids (Oncorhynchus spp.) in impounded river systems
}

\author{
Tobias J. Kock (1D) John W. Ferguson • Matthew L. Keefer (1D) Carl B. Schreck
}

Received: 29 June 2020/ Accepted: 31 October 2020

(C) The Author(s) 2020

\begin{abstract}
High-head dams are migration barriers for Pacific salmon Oncorhynchus spp. in many river systems and recovery measures for impacted stocks are limited. Trap-and-haul has been widely used in attempts to facilitate recovery but information from existing programs has not been synthesized to inform improvements to aid recovery of salmonids in systems with high-head dams. We reviewed 17 trap-and-haul programs regarding Pacific salmon to: (1) summarize information about facility design, operation and biological effects; (2) identify critical knowledge gaps; and (3) evaluate trap-and-haul as a current and future management tool. Existing programs are operated to address a range of management goals including restoring access to historical habitats, temporarily
\end{abstract}

T. J. Kock ( $\square)$

U.S. Geological Survey, Western Fisheries Research Center, 5501A Cook-Underwood Road, Cook, WA 98605, USA

e-mail: tkock@usgs.gov

J. W. Ferguson

Anchor QEA, LLC, 1201 3rd Avenue \#2600, Seattle, WA 98101, USA

\section{L. Keefer}

Department of Fish and Wildlife Sciences, College of Natural Resources, University of Idaho, 875 Perimeter

Drive, Moscow, ID 83844-1136, USA

C. B. Schreck

Department of Fisheries and Wildlife, Oregon State, University, Corvallis, OR 97331, USA reducing exposure to dangerous in-river conditions, and reintroducing ecological processes upstream from dams. Information gathered from decades of operation on facility design criteria and fish handling protocols, and robust literature on fish collection and passage are available. While many aspects of trap-and-haul have been evaluated, effects on population productivity and sustainability remain poorly understood. Long-term and systematic studies of trap-and-haul outcomes are rare, and assessments can be confounded by concurrent management actions and broad ecological and climatic effects. Existing data suggest that performance and effectiveness vary among programs and over various time scales within programs. Although critical information gaps exist, trap-and-haul is an important management and conservation tool for providing Pacific salmonids access to historical habitats. Successful application of trap-and-haul programs requires long-term commitment and an adaptive management approach by dam owners and stakeholders, and careful planning of new programs.

Keywords Pacific salmon · Trap-and-haul · Oncorhynchus · Dams · Passage · Impoundments 


\section{Introduction}

Dams provide many benefits worldwide including flood control, municipal and agricultural water supplies, and hydropower generation. However, these structures and the reservoirs they create are often barriers to movement for migratory fishes and other aquatic species. Fish mortality has been directly attributed to dam passage (Čada 2001; Muir et al. 2001; Skalski et al. 2002; Schilt 2007; Larinier 2008) and to indirect effects from factors such as predation, migration delay, pathogen transmission, and thermal perturbations (Poe et al. 1991; Clarkson and Childs 2000; Schreck et al. 2006; Keefer et al. 2012; Colvin et al. 2015). Substantial efforts have focused on developing safe and effective fish passage options for upstream (Clay 1995; Roscoe and Hinch 2010; Bunt et al. 2012; Katopodis and Williams 2012; Pompeu et al. 2012; Williams et al. 2012) and downstream migrants at dams (Ferguson et al. 2007; Schilt 2007; Adams et al. 2014; Shi et al. 2015; Skalski et al. 2016; Fjelstad et al. 2018). Unfortunately, fish passage facilities have often failed to fully mitigate negative effects of dams and their impoundments (Nicola et al. 1996; Caudill et al. 2007; Fukushima et al. 2007; Ferguson et al. 2011).

In some river systems, resource managers have elected to collect migrants and transport them (hereafter trap-and-haul; Fig. 1) past dams, impoundments, and other migration barriers to facilitate migration and dispersal. Trap-and-haul has been used as a routine fisheries management tool (Sigourney et al. 2015) and as a conservation strategy to maintain or restore fish populations upstream from dams without fish passage (Sard et al. 2016; Lusardi and Moyle 2017). Additionally, trap-and-haul has been employed as an emergency procedure to protect endangered Snake River sockeye salmon (Oncorhynchus nerka) when inriver migratory conditions become hazardous (Kozfkay et al. 2017). While volitional passage of Pacific salmon (Oncorhynchus spp.) at barriers is preferred over passage that requires collection and transportation (e.g., NMFS 2011), volitional passage at many locations is constrained by economic or engineering considerations. At many high-head dams $(>30 \mathrm{~m}$ tall), for example, fishway construction may be unrealistic, leaving trap-and-haul or dam removal as the only potentially viable options for sustaining or reintroducing populations upstream of the dam.
Trap-and-haul is being used to restore connectivity to reaches both downstream and upstream of dams. Programs typically rely on collection facilities located in a dam forebay (reviewed by Kock et al. 2019a) to collect juvenile migrants for downstream transport whereas adult migrants are captured for upstream transport in trapping facilities located in a dam tailrace (NMFS 2011). In some cases, O. mykiss kelts, adult steelhead that have successfully spawned and are returning to the ocean, are also collected and transported downstream (Trammell et al. 2016). Transport of juveniles and adults to in-river release sites is generally accomplished using fish-hauling tanker trucks with the capability to provide supplemental oxygen for fish during transport (Sigourney et al. 2015; DeWeber et al. 2017; Colvin et al. 2018). However, at some Columbia River dams, juveniles (Ward et al. 1997; McMichael et al. 2011) or downstream-migrating adults (Evans et al. 2008) are transported in barges with flow-through or recirculating river water. For all transport methods, protocols have been developed to protect fish during transit. A main goal of these protocols is to minimize fish stress. For example, maximum fish density thresholds are used to ensure that fish are not overcrowded while inside holding and transport tanks. Water temperatures and dissolved oxygen levels are monitored and maintained during transport and fish are loaded and released using water-to-water transfer methods. Additionally, fish are sometimes released into "stress-relief ponds" after transport which has been shown to attenuate the effects of stress incurred during the holding and transport (NMFS 2011).

Existing trap-and-haul programs are operated to provide passage for either juveniles or adults (hereafter one-way trap-and-haul), or for multiple life stages (juveniles downstream and adults upstream, hereafter two-way trap-and-haul; Lusardi and Moyle 2017). Some trap-and-haul programs have been operating for decades (Table 1), especially in the U.S. Pacific Northwest where hydropower development has contributed to widespread Pacific salmonid population declines and extirpations (Nehlsen et al. 1991; Kareiva et al. 2000; McClure et al. 2003).

Although some programs have operated for decades, efforts to review and synthesize the effectiveness of trap-and-haul as a fish conservation and management strategy are lacking. In some cases, individual elements of the trap-and-haul process (i.e., juvenile 


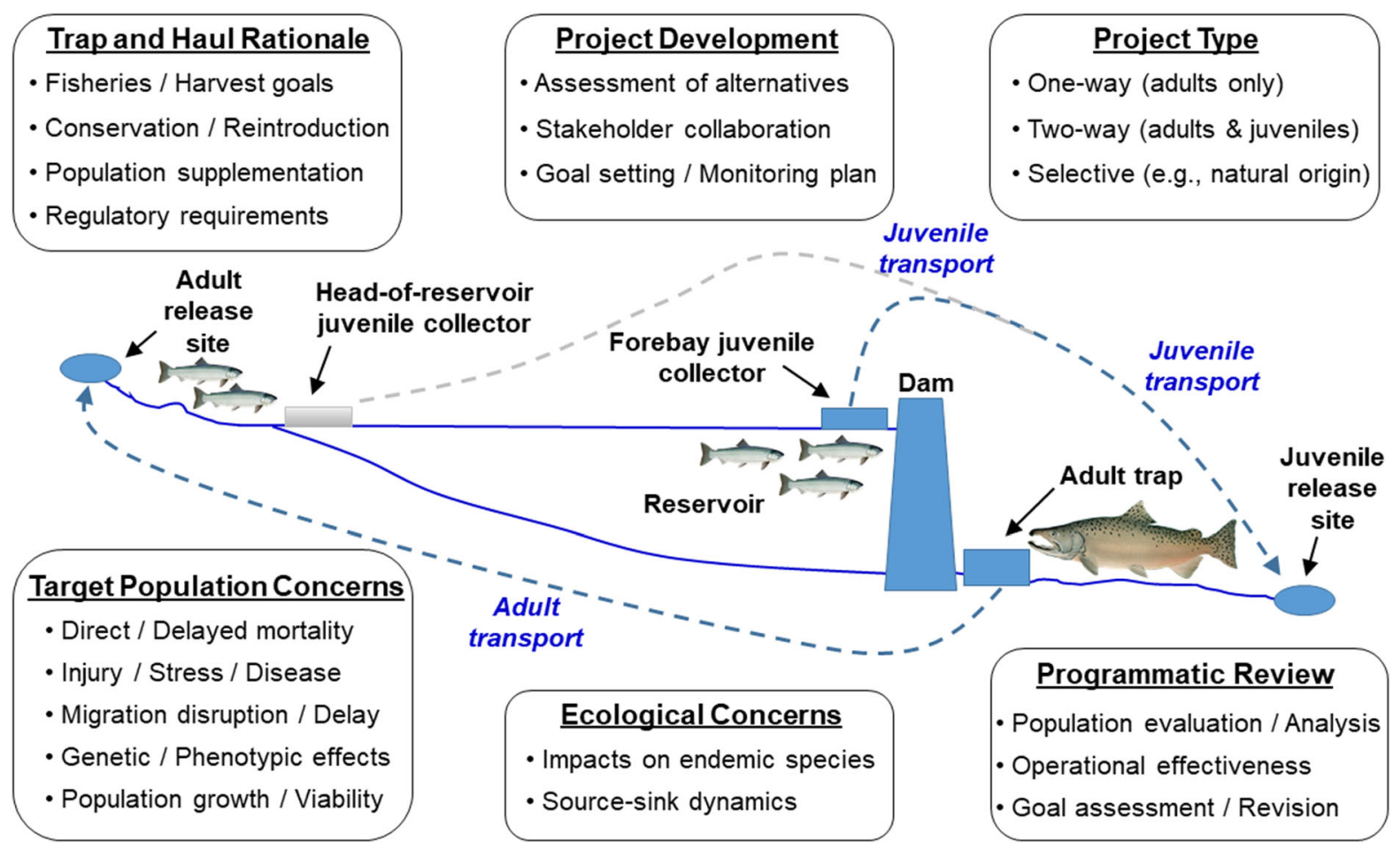

Fig. 1 Conceptual diagram of a two-way trap-and-haul program and key elements considered in program development

collection efficiency, adult prespawn mortality) have been evaluated. However, a comprehensive assessment is needed to evaluate if the strategy should continue to be used at existing and new locations. In a recent review, Lusardi and Moyle (2017) assessed two-way trap-and-haul as a conservation tool, with an emphasis on potential application for threatened Chinook salmon (O. tshawytscha) in central California. The authors reviewed several existing two-way (i.e., both downstream juvenile and upstream adult transport) trap-and-haul programs in the Pacific Northwest, highlighted potential risks of fish transport, and provided recommendations for effective characteristics of two-way trap-and-haul programs. These included establishing clearly defined success metrics, confirming that adequate spawning, incubation, and rearing habitats exist in recipient rivers, and that twoway trap-and-haul be conducted as part of a more comprehensive program that includes other management actions such as habitat restoration and dam removal (Lusardi and Moyle 2017). They concluded that no two-way trap-and-haul program was an unequivocal success and that new programs should proceed with extreme caution. The authors provided valuable insights into several aspects of trap-and-haul but provided limited information on what has been learned about developing and operating trap-and-haul facilities, handling and transporting fish, or how fish respond biologically to trap-and-haul.

Given that trap-and-haul operations have occurred for nearly 100 years in the Pacific Northwest and that there is continued interest in using trap-and-haul at existing and new locations (Clancey et al. 2017; Hardiman et al. 2017; Herbold et al. 2018; Upper Columbia United Tribes 2019), we conducted this review to: (1) summarize information about facility design and operation and the biological effects of trapand-haul in the U.S. Pacific Northwest; (2) identify critical knowledge gaps; and (3) evaluate trap-andhaul as a current and future management tool. To address these objectives, we focused on trap-and-haul operations for Pacific salmonids at dams without volitional fish passage facilities. We also include examples of where trap-and-haul is used to circumvent other impediments to illustrate the breadth of trap-andhaul applications. To address how fish respond to trapand-haul we reviewed literature from existing trapand-haul sites and other established salmonid transport 
Table 1 Trap-and-haul locations, program type, fish species, and transport distance

\begin{tabular}{|c|c|c|c|c|}
\hline Location & Year program began & Species transported & $\begin{array}{l}\text { Approximate number } \\
\text { of fish transported }\end{array}$ & $\begin{array}{l}\text { Approximate } \\
\text { transport time } \\
(\mathrm{min})\end{array}$ \\
\hline \multicolumn{5}{|c|}{ Two-way trap-and-haul programs } \\
\hline $\begin{array}{l}\text { Baker River, } \\
\text { Washington }\end{array}$ & $\begin{array}{l}\text { Adult program began in } 1925 \\
\text { Juvenile program began in } 1958\end{array}$ & $\mathrm{SO}, \mathrm{CO}, \mathrm{CT}$ & $\begin{array}{l}\text { Adults }=10,000 \mathrm{~s} \\
\text { Juveniles }=100,000 \mathrm{~s}\end{array}$ & $\begin{array}{l}\text { Adults }=60 \mathrm{~min} \\
\text { Juveniles }=20, \\
60 \mathrm{~min}\end{array}$ \\
\hline $\begin{array}{l}\text { Cowlitz River, } \\
\text { Washington }\end{array}$ & $\begin{array}{l}\text { Adult program began in } 1994 \\
\text { Juvenile program began in } 1995\end{array}$ & $\mathrm{ST}, \mathrm{CK}, \mathrm{CO}, \mathrm{CT}$ & $\begin{array}{l}\text { Adults }=10,000 \mathrm{~s} \\
\text { Juveniles }=100,000 \mathrm{~s}\end{array}$ & $\begin{array}{l}\text { Adults }=30,45, \\
90 \mathrm{~min} \\
\text { Juveniles }=45 \mathrm{~min}\end{array}$ \\
\hline $\begin{array}{l}\text { Deschutes River, } \\
\text { Oregon }\end{array}$ & $\begin{array}{l}\text { Adult program began in } 2012 \\
\text { Juvenile program began in } 2009\end{array}$ & $\mathrm{SO}, \mathrm{CK}, \mathrm{ST}, \mathrm{BT}$ & $\begin{array}{l}\text { Adults }=10 \mathrm{~s} \\
\text { Juveniles }=100,000 \mathrm{~s}\end{array}$ & $\begin{array}{l}\text { Adults }=45 \mathrm{~min} \\
\text { Juveniles }=45 \mathrm{~min}\end{array}$ \\
\hline $\begin{array}{l}\text { Lewis River, } \\
\text { Washington }\end{array}$ & $\begin{array}{l}\text { Adult program began in } 2005 \\
\text { Juvenile program began in } 2012\end{array}$ & $\mathrm{ST}, \mathrm{CK}, \mathrm{CO}, \mathrm{CT}$ & $\begin{array}{l}\text { Adults }=10,000 \mathrm{~s} \\
\text { Juveniles }=10,000 \mathrm{~s}\end{array}$ & $\begin{array}{l}\text { Adults }=90 \mathrm{~min} \\
\text { Juveniles }=45 \mathrm{~min}\end{array}$ \\
\hline $\begin{array}{l}\text { North Fork Skokomish } \\
\text { River, Washington }\end{array}$ & Juvenile program began in 2015 & $\mathrm{SO}, \mathrm{CO}$ & Juveniles $=10,000 \mathrm{~s}$ & Juveniles $=20 \mathrm{~min}$ \\
\hline \multicolumn{5}{|c|}{ Upstream transport trap-and-haul programs } \\
\hline Fall Creek, Oregon & Adult program began 1965 & CK & $100 \mathrm{~s}$ & $15 \min$ \\
\hline $\begin{array}{l}\text { McKenzie River, } \\
\text { Oregon }\end{array}$ & Adult program began in 1993 & $\begin{array}{l}\mathrm{CK}, \mathrm{BT}, \mathrm{RT}, \mathrm{CT} \\
\mathrm{WF}\end{array}$ & $100 \mathrm{~s}$ & $60 \mathrm{~min}, 120 \mathrm{~min}$ \\
\hline $\begin{array}{l}\text { Middle Fork Willamette } \\
\text { River, Oregon }\end{array}$ & Adult program began in 1994 & CK & $1000 \mathrm{~s}$ & $\begin{array}{l}90 \mathrm{~min}, 150 \mathrm{~min} \text {, } \\
210 \mathrm{~min}\end{array}$ \\
\hline $\begin{array}{l}\text { North Santiam River, } \\
\text { Oregon }\end{array}$ & Adult program began in 2000 & CK & $1000 \mathrm{~s}$ & $\begin{array}{l}25 \mathrm{~min}, 30 \mathrm{~min} \text {, } \\
40 \mathrm{~min}\end{array}$ \\
\hline $\begin{array}{l}\text { Snake River, } \\
\text { Washington }^{\mathrm{a}}\end{array}$ & Adult program began in 2001 & SO & $100 \mathrm{~s}$ & $210 \mathrm{~min}$ \\
\hline $\begin{array}{l}\text { South Fork Skykomish } \\
\text { River, Washington }\end{array}$ & Adult program began in 1958 & $\begin{array}{l}\text { ST, CO, SO, CK, } \\
\text { CT, PS, CH, BT }\end{array}$ & $10,000 \mathrm{~s}$ & $20 \mathrm{~min}$ \\
\hline $\begin{array}{l}\text { South Santiam River, } \\
\text { Oregon }\end{array}$ & Adult program began in 1967 & ST, CK & $1000 \mathrm{~s}$ & $\begin{array}{l}10 \mathrm{~min}, 20 \mathrm{~min} \text {, } \\
45 \mathrm{~min}\end{array}$ \\
\hline $\begin{array}{l}\text { Toutle River, } \\
\text { Washington }\end{array}$ & Adult program began in 1988 & $\mathrm{ST}, \mathrm{CO}, \mathrm{CT}$ & $100 \mathrm{~s}$ & $\begin{array}{l}10 \mathrm{~min}, 20 \mathrm{~min} \text {, } \\
40 \mathrm{~min}\end{array}$ \\
\hline $\begin{array}{l}\text { Wynoochee River, } \\
\text { Washington }\end{array}$ & Adult program began in 1972 & $\mathrm{ST}, \mathrm{CO}, \mathrm{CK}$ & $1000 \mathrm{~s}$ & $20 \mathrm{~min}$ \\
\hline $\begin{array}{l}\text { White River, } \\
\text { Washington }\end{array}$ & Adult program began in 1941 & $\begin{array}{l}\text { CK, ST, CO, PS, } \\
\text { BT, CH }\end{array}$ & $100,000 \mathrm{~s}$ & $30 \mathrm{~min}$ \\
\hline $\begin{array}{l}\text { Yakima River, } \\
\text { Washington }\end{array}$ & Adult program began in 2009 & SO & $1000 \mathrm{~s}$ & $120 \mathrm{~min}$ \\
\hline $\begin{array}{l}\text { Elwha River, } \\
\text { Washington }\end{array}$ & Adult program began in 2012 & $\mathrm{CO}$ & $100 \mathrm{~s}$ & $45 \min$ \\
\hline
\end{tabular}

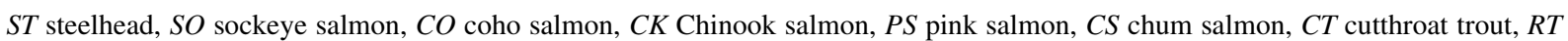
rainbow trout, $B T$ bull trout

${ }^{a}$ Adult sockeye salmon are transported from the Stanley Basin to a conservation hatchery near Boise, Idaho for holding, then back to the Stanley Basin for spawning. In 2015 fish were captured at Lower Granite Dam to save them from dangerous in-river conditions

programs with directly relevant research results. The summaries and recommendations herein are intended to improve management and monitoring strategies in existing programs and inform discussions among resource managers and stakeholders at sites where trap-and-haul is being considered. 


\section{Upstream migrant trap-and-haul programs}

Upstream migrant trap-and-haul is the most common type of trap-and-haul program currently used in the Pacific Northwest. Most of these programs are operated to move returning adult salmon and steelhead around high-head dams where they are released to spawn naturally. In some cases, these programs are used to move fish around natural barriers, areas affected by natural disaster, or to remove endangered fish from dangerous in-river conditions below dams. These programs rely on fish traps to collect upstream migrants and transport is by fish-hauling trucks.

\section{Willamette River basin, Oregon}

Numerous upstream migrant trap-and-haul programs are operated in the Willamette River basin, Oregon. The U.S. Army Corps of Engineers (USACE) operates the Willamette Valley Project, a group of 13 dams that provide flood risk management, power generation, and other societal benefits. Eleven of the dams are highhead projects that were built during the 1950s-1960s and block spring-run Chinook salmon and winter-run steelhead from historical upstream habitats (NMFS 2008). In the early 1990s, the Oregon Department of Fish and Wildlife (ODFW) began transporting and releasing surplus hatchery Chinook salmon adults upstream of several Willamette River dams to evaluate the feasibility of re-establishing anadromous populations (NMFS 2008). These early releases resulted in the successful production of offspring that moved downstream and attempted to pass dams (Keefer et al. 2012, 2013), which led to the integration of adult trapand-haul into the fish recovery program for the basin (NMFS 2008). Upstream transport of adults in the Willamette basin occurs in Fall Creek, and the McKenzie, Middle Fork Willamette, North Santiam, and South Santiam rivers (Table 1). The goals of individual tributary programs differ (Sharpe et al. 2016), and safe downstream fish passage through reservoirs and past dams are key limitations to population expansion in several tributaries (Keefer et al. 2012, 2013; Monzyk et al. 2015a, b; Romer et al. 2016).

Trap-and-haul of adult spring-run Chinook salmon at Fall Creek Dam (rkm 12; height $=64 \mathrm{~m}$ ) began in 1965 during dam construction. Adult transport occurred for several years after the dam was completed but was then abandoned until the program was re-started in 1991. Returning Chinook salmon are collected from the tailrace of the dam via an adult fishway and trap and transported upstream by truck $15 \mathrm{~min}$ to a release site upstream of the reservoir. The average annual number of adults transported in 1991-2018 was 470 fish with a peak of 2805 adults in 2004 (data provided by Greg Taylor, USACE). The program goal is population recovery upstream of Fall Creek Dam (Sharpe et al. 2016). Progeny of transported adults move downstream and enter Fall Creek Reservoir. Passage options are limited at the dam so most juvenile Chinook salmon rear in the reservoir during their first year (Monzyk et al. 2015a). In recent years, Fall Creek Reservoir has been drained in November to flush juvenile salmon downstream and to reduce populations of non-native piscivores that prey on salmon in the reservoir (Murphy et al. 2019). Although the Fall Creek salmon population was nearly extirpated, it is currently self-sustaining and is one of the few natural-origin-only Chinook salmon populations in the Willamette basin.

The McKenzie River supports the most abundant population of spring-run Chinook salmon in the Willamette River basin (Myers 2017). Access to headwater tributaries in the McKenzie River is blocked by Blue River Dam (rkm 3 of the Blue River; height $=82 \mathrm{~m})$, Cougar Dam (rkm 7 of the South Fork McKenzie River; height $=158 \mathrm{~m}$ ), and Trail Bridge Dam (rkm 124 of the McKenzie River; height = 31 $\mathrm{m})$, which were all constructed in the 1960s. Trap-andhaul efforts in the McKenzie River were initiated in 1993 using adult Chinook salmon collected at hatchery traps. The McKenzie River program moves adults upstream of Trail Bridge and Cougar dams. In 2010, a new adult collection facility was completed in the Cougar Dam tailrace. This facility serves as the collection point for unmarked (i.e., presumed naturalorigin) Chinook salmon that return to the South Fork McKenzie River. Both natural-origin and hatcheryorigin Chinook salmon are transported upstream of Cougar Reservoir but are segregated by release site with hatchery-origin fish released farther upstream than natural-origin fish. The goal of the natural-origin releases is to recover Chinook salmon populations in the upper South Fork McKenzie River while the goal of the hatchery-origin releases is to produce prey for bull trout (Salvelinus confluentus) residing in the upper system. The average annual number of adult 
Chinook salmon transported around McKenzie River dams was 1382 fish in 1993-2018. In 2014, the USACE constructed an experimental floating collector designed to collect downstream migrants in the Cougar Dam forebay. That device was operated for two collection seasons but collected few fish (Beeman et al. 2016a, b) which led to a decision to abandon its use. A new, larger surface collector is being designed to provide downstream passage at Cougar Dam. Improvement to downstream fish passage and survival at Cougar Dam is considered critically important for establishing viable Chinook salmon populations in the upper South Fork McKenzie River basin. Reintroduction efforts have not been initiated upstream of Trail Bridge Dam, so there are currently no plans for constructing downstream fish passage facilities at this dam, and natural-origin Chinook salmon are not transported upstream of the dam. Adult hatcheryorigin Chinook salmon are transported upstream of Trail Bridge Dam for the sole purpose of providing juvenile salmon as prey for bull trout.

Trap-and-haul in the Middle Fork Willamette River is a complex process with multiple purposes (Sharpe et al. 2016). Adult trapping occurs at Dexter Dam (rkm 29; height $=36 \mathrm{~m}$ ), the downstream-most dam in the Middle Fork Willamette River, and at Willamette Hatchery (rkm 2) with releases conducted at multiple sites in various upstream reaches and tributaries. The intent of the adult releases includes restoring biological contributions of salmon to the ecosystem, providing forage for native bull trout that were recently reintroduced, and supporting research on Chinook salmon prespawn mortality (Sharpe et al. 2016; Myers 2017). Middle Fork Willamette River reservoirs have high growth opportunity for juvenile salmonids but contain large populations of predatory fishes and consequently juvenile mortality rates can be high (Brandt et al. 2016; Kock et al. 2019b). Juvenile Chinook salmon primarily pass dams during fall and winter months in the Middle Fork Willamette River when reservoir elevations are relatively low and deepwater passage routes are available at the dams, though passage mortality through these routes can be quite high (Keefer et al. 2012, 2013).

On the North Santiam River, trap-and-haul has been used to reintroduce Chinook salmon upstream from Detroit Dam (rkm 79; height = $141 \mathrm{~m})$, which currently lacks downstream fish passage facilities. While winter-run steelhead also historically occupied the upper North Santiam basin, steelhead reintroduction efforts are on hold until downstream fish passage is available at Detroit Dam (Mapes et al. 2017). Trapand-haul operations in the North Santiam River began in 2000 (Table 1) using an adult collection and holding facility located at Minto Dam (rkm 67; 4 m), downstream of Detroit and Big Cliff (rkm 74; height $=58$ m) dams; a rebuilt Minto Fish Facility began operating in 2013. The North Santiam reintroduction effort relies on transporting hatchery-origin Chinook salmon 25-40 min upstream from Detroit Reservoir where they are released at three tributary locations. The mean annual number of adult Chinook salmon transported upstream of Detroit Dam was 1307 fish during 2000-2018 (data provided by Greg Grenbemer, ODFW). Studies have shown that juvenile outmigrants can pass Detroit Dam through turbines or over spillways (Beeman and Adams 2015; Kock et al. 2015) where substantial mortality can occur (Normandeau 2010). As a result, Myers (2017) recommended that reintroduction plans for Chinook salmon and steelhead upstream of Detroit Dam be synchronized with the development of juvenile passage facilities at the dam. The USACE is currently designing selective water withdrawal and floating screen structures that will be hydraulically connected and work together to collect downstream migrants in the dam forebay and allow the temperature of water passing the dam to be controlled. This temperature control is critical for supporting spawning, rearing, and migration of salmonids downstream of the dam.

Anadromous fish management objectives are unique in the South Santiam River relative to other Willamette River tributaries. Natural-origin winterrun steelhead adults have been transported upstream of Foster Dam $(\mathrm{rkm} \mathrm{62}$; height $=38 \mathrm{~m})$ since it began operating in 1968 and trap-and-haul of adult Chinook salmon began in 1996. Currently, these programs transport only natural-origin fish of both species with the objective of increasing natural production and reducing the influence of hatchery fish on the basin's populations (Evans et al. 2016; Sharpe et al. 2016; Wiegel et al. 2019). Adult collection initially relied on a fish trap that was included in the original construction of Foster Dam in 1968. That structure was replaced with a new adult collection facility consisting of a fishway and trap located adjacent to the Foster Dam tailrace in 2014. The mean annual number of adults transported upstream during 1996-2018 was 
979 Chinook salmon (1996-2018) and 580 steelhead (1967-2018). Collected adults are transported upstream to several release locations, including the head of Foster Reservoir (Sharpe et al. 2016; DeWeber et al. 2017; Naughton et al. 2018). Downstream migrants at Foster Dam pass through turbines, spillbays, or through a weir designed to facilitate downstream passage; juvenile fish passage efficiencies and survival rates have generally been higher at Foster Dam than at other Willamette Project dams (Hughes et al. 2014, 2016). The overall success of the South Santiam program can be attributed to the efficacy of the adult trap-and-haul program and relatively successful juvenile passage, though several challenges remain (Myers 2017). Evans et al. (2016) reported Chinook salmon cohort replacement rate for fish transported upstream exceeded 1.0 during three consecutive years (2007-2009). Cohort replacement rate refers to the number of adults that return to spawn in a given site compared to the number of adults that were transported upstream to produce those fish.

Although trap-and-haul is used throughout the Willamette River basin to move adult Chinook salmon and steelhead upstream of project dams, most of these programs are not ready to be assessed for effectiveness in population recovery because downstream fish passage facilities are not present at most dams. Most programs are currently operated to maintain ecological functions provided by anadromous fish presence (i.e., nutrient enhancement, forage for other fish populations) and support research aimed at improving trap-and-haul methods but cannot fully address the fragmentation caused by dams across the entire life cycle. It is anticipated that these programs will eventually move towards the goal of recovering anadromous fish populations upstream of project dams when downstream fish passage facilities are developed and deployed.

\section{White River, Washington}

Numerically, the trap-and-haul program on the White River, Washington, is the largest adult transport program operating in the Pacific Northwest. The program began in 1941 while Mud Mountain Dam $(\mathrm{rkm} 45$; height $=132 \mathrm{~m})$ was under construction and trap-and-haul is used to transport Chinook salmon, coho salmon, steelhead, sockeye salmon, chum salmon $O$. keta, pink salmon $O$. gorbuscha, bull trout, mountain whitefish Prosopium williamsoni, rainbow trout (resident $O$. mykiss), and cutthroat trout around the dam (Fig. 2). On average, 147,307 fish were transported annually during 2000-2017, which included a peak count of 650,336 fish in 2011. Several factors have contributed to adult returns of this magnitude. In the mid-1980s, hatchery production of spring-run Chinook salmon began on the White River, minimum instream flow requirements were established, and fish screens were added to water diversions in 1997 (personal communication, Fred Goetz, USACE). Additionally, pink salmon began returning to the fish trap at Mud Mountain Dam in 1995. Regionally, pink salmon predominantly return in odd numbered years. The average number of pink salmon transported and released upstream of Mud Mountain Dam in odd numbered years during 2000-2017 was 293,681 fish. The existing fish facility was designed to handle approximately 20,000 fish each year, so a new facility designed to collect up to $60,000 \mathrm{fish} / \mathrm{d}$ is currently under construction that will be the largest adult fish collection and transport facility in the United States. Overall, the number of adults and species collected and transported annually at Mud Mountain Dam has increased substantially since the 1980s (Fig. 2).

\section{Skykomish River, Washington}

On the South Fork Skykomish River, trap-and-haul is used to transport tens of thousands of adult salmonids around a series of impassable waterfalls (Sunset, Canyon and Eagle Falls; 7.6-31.7 $\mathrm{m}$ tall). The program began in 1958 to provide access to quality spawning and rearing habitat that would otherwise be unavailable to anadromous fish and expand fishery opportunities on salmonid stocks in the Snohomish River, a large tributary to Puget Sound. To implement the program, a fish ladder and sorting facility were constructed downstream of Sunset Falls (rkm 84). At the sorting facility, hatchery fish can be removed when required by protocols (personal communication, Ed Eleazer, Washington Department of Fish and Wildlife [WDFW]). Upstream transport ( $20 \mathrm{~min})$ is conducted for coho salmon, Chinook salmon, pink salmon, chum salmon, sockeye salmon, steelhead, bull trout and cutthroat trout (Table 1). The mean annual number of fish transported from 1958 to 2018 was 25,447 , and the peak number transported was 


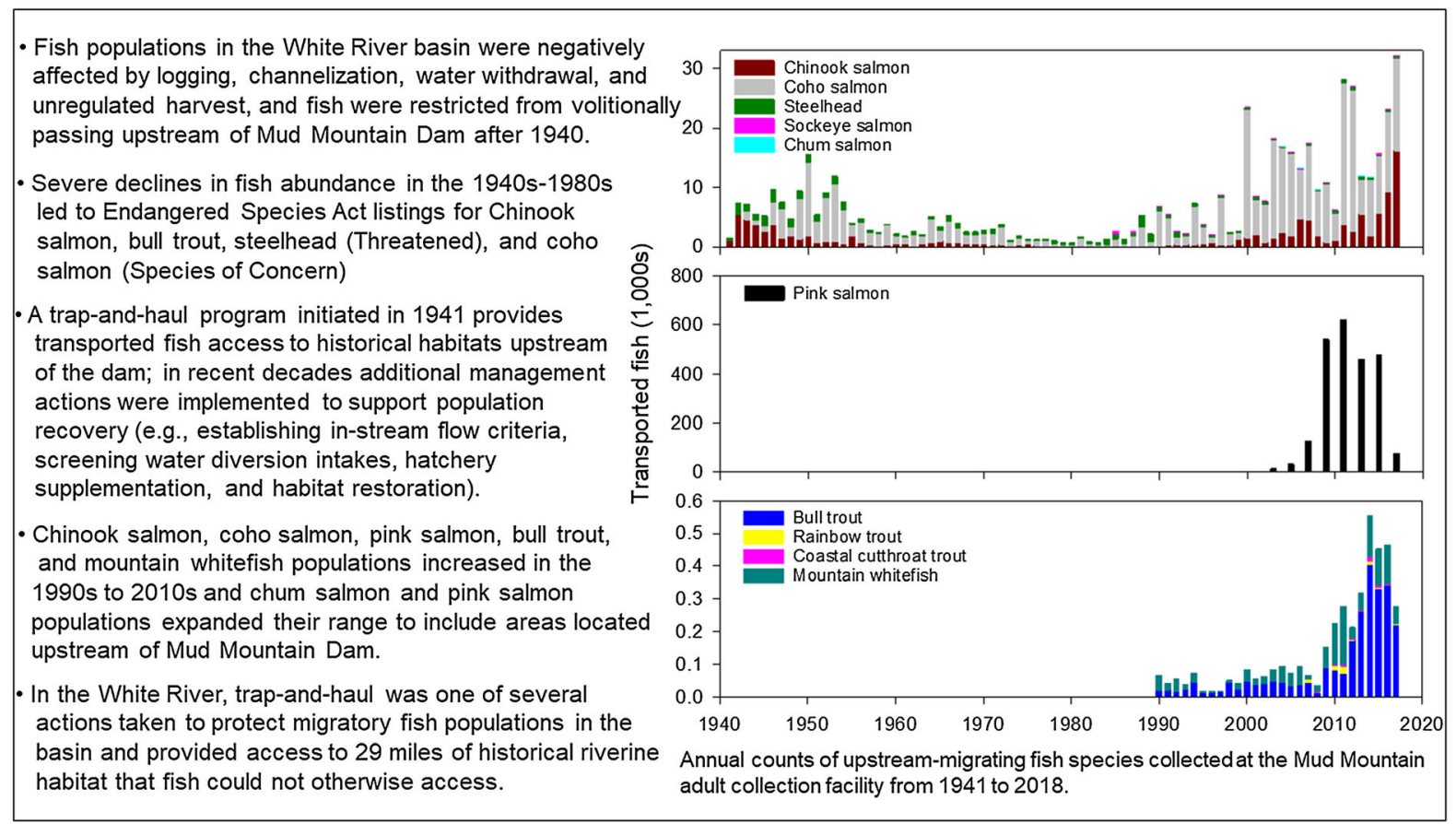

Fig. 2 Seventy-eight years of adult trap-and-haul: Mud Mountain Dam on the White River, Washington

124,228 fish in 2009. Juvenile passage occurs volitionally as the waterfalls do not prevent outmigration.

Toutle River, Washington

The 1980 eruption of Mount St. Helens had catastrophic effects on aquatic communities in the North Fork Toutle River, Washington (Major et al. 2000). The upper $25 \mathrm{~km}$ of the river were buried in a layer of mud, ash and debris estimated to be $45 \mathrm{~m}$ deep (Voigt et al. 1981; Glicken 1998). In 1987, the USACE began construction of a sediment retention structure (SRS; height $=56 \mathrm{~m}$ ) designed to trap sediments upstream of the structure and minimize downstream sediment accumulation. The SRS was not designed with fish passage capabilities, so a fish collection structure was also constructed $3.2 \mathrm{~km}$ downstream from the SRS (Loch and Downing 1990). Since 1989, WDFW has been using the Toutle River fish collection facility to trap adult coho salmon, winter-run steelhead, and cutthroat trout for transport upstream of the SRS. Transported fish are released directly into three tributaries of the North Fork Toutle River with transport times ranging from 10-40 min. Progeny of transported adults can move downstream volitionally and pass through a spillway located on the side of the SRS. Overall, the number of adult fish collected and transported under this program is small and averaged 198 winter-run steelhead and 202 coho salmon each year from 1989 to 2018 (WDFW, unpublished data).

Wynoochee River, Washington

Trap-and-haul is used to transport adult steelhead, coho salmon and Chinook salmon around Wynoochee Dam $(\mathrm{rkm} 80$; height $=53 \mathrm{~m})$ and reservoir, located on a major tributary to the Chehalis River. The program began operating in 1972 when Wynoochee Dam was constructed. Fish collection occurs two miles downstream of the dam where fish are prevented from moving upstream by a low-head barrier dam. At the barrier dam fish are diverted into a series of pools that terminate in a large holding pool. On hauling days fish are removed from the holding pool and trucked 20 min upstream to a release site located upstream of Wynoochee Reservoir. We were unable to access data describing the number of fish transported annually on the Wynoochee River. Juvenile passage is facilitated by not operating the dam's turbines for 77 consecutive days each year during the primary outmigration period 
which allows fish to pass through downstream passage outlets rather than through the turbines.

\section{Yakima River, Washington}

Adult trap-and-haul has been used to reintroduce sockeye salmon in the Yakima River basin. Four natural glacial lakes in the upper Yakima River basin historically supported sockeye salmon populations that were extirpated in the early 1900 s due to dam construction (Bureau of Reclamation [BOR] 2007). In 2009, the Confederated Tribes and Bands of the Yakama Nation (Yakama Nation) began reintroducing adult sockeye salmon into Cle Elum Reservoir, a lake historically used by sockeye salmon in the basin that was modified by the construction of Cle Elum Dam $(\mathrm{rkm} 345$; height $=150 \mathrm{~m})$ at the natural lake outlet (Matala et al. 2019). The reintroduction is using donor stocks of sockeye salmon from Osoyoos Lake (British Columbia-Washington) and Lake Wenatchee (Washington). Adults from the two populations are collected using an adult trap at Priest Rapids Dam (rkm 639; height $=54 \mathrm{~m}$ ) on the Columbia River in eastern Washington (Matala et al. 2019). Trapped sockeye salmon adults are trucked from Priest Rapids Dam to Cle Elum Reservoir with a transport time of $\sim 2 \mathrm{~h}$. The number of fish available for transport varies annually based on the total run size of sockeye salmon in the Columbia River. The average annual number of transported sockeye salmon was 5760 fish during 2009-2018. Outplanted adults spawn in Cle Elum Reservoir and upstream in the Cle Elum River (Matala et al. 2019). A single downstream passage route, located in one of the dam's spillbays, is seasonally available for juvenile outmigrants at Cle Elum Dam when reservoir water levels are sufficiently high. Sockeye salmon adults began returning to the Yakima River in 2013 as a result of reintroduction efforts with an average of 1160 fish returning annually during 2013-2019 (data courtesy of Yakama Nation Fisheries). The BOR, who owns and operates Cle Elum Dam, is currently working to construct on-site juvenile and adult collection facilities to support this effort (BOR 2011). The long-term plan is to reintroduce sockeye salmon to all lakes historically used by sockeye salmon in the Yakima River Basin (BOR 2012).

The strategy of using two separate stocks of adult sockeye salmon in the reintroduction effort has yielded interesting results. Matala et al. (2019) found that fish from the two populations exhibited spatial and temporal separation during the spawning period, with adults originating from Lake Wenatchee spawning earlier and farther upstream than adults from Osoyoos Lake. Genetic analysis of samples taken from smolts and returning adults found that $5 \%$ or less of the sampled fish were hybrids produced from mixed-stock matings. The authors also found that smolts produced in Cle Elum Reservoir were significantly larger at emigration (average of $140 \mathrm{~mm}$ and $129 \mathrm{~mm}$ for Osoyoos-origin and Wenatchee-origin, respectively) than smolts emigrating from either Osoyoos Lake or Lake Wenatchee (84 mm average; Matala et al. 2019). Differences in reproductive success were also evident as $70 \%$ of the smolts sampled were produced from parents from Lake Wenatchee. This transferred to cohort replacement rates as well, as the Lake Wenatchee stock had a replacement rate of 0.80 compared to 0.17 for Osoyoos Lake stock (Matala et al. 2019). Over the course of the study (2013-2016), $53 \%$ of the adults that were outplanted into Cle Elum Reservoir were of Lake Wenatchee-origin, $43 \%$ were of Osoyoos Lake-origin, and the remaining fish were hybrids. These results show that genetic studies can be useful for assessing how fish from different source populations adapt to a novel environment after trapand-haul.

\section{Two-way trap-and-haul programs}

Two-way trap-and-haul is generally defined as downstream trap and transport of juvenile fish and upstream trap and transport of adult fish around a dam or other passage obstacle (Lusardi and Moyle 2017). Two-way trap-and-haul programs are operated on four rivers in the northwestern United States including the Baker, Cowlitz, and Lewis rivers in Washington and the Deschutes River in Oregon (Fig. 3). At these locations trap-and-haul is used to move fish around multiple high-head dams (>30 m) and reservoirs. In addition to the existing programs, two-way trap-and-haul programs are planned for the North Fork Skokomish River (Washington), on several Willamette River tributaries (Oregon), and are being considered on the upper Columbia River (Washington, British Columbia), upper Sacramento River (California), and other river systems in California. 


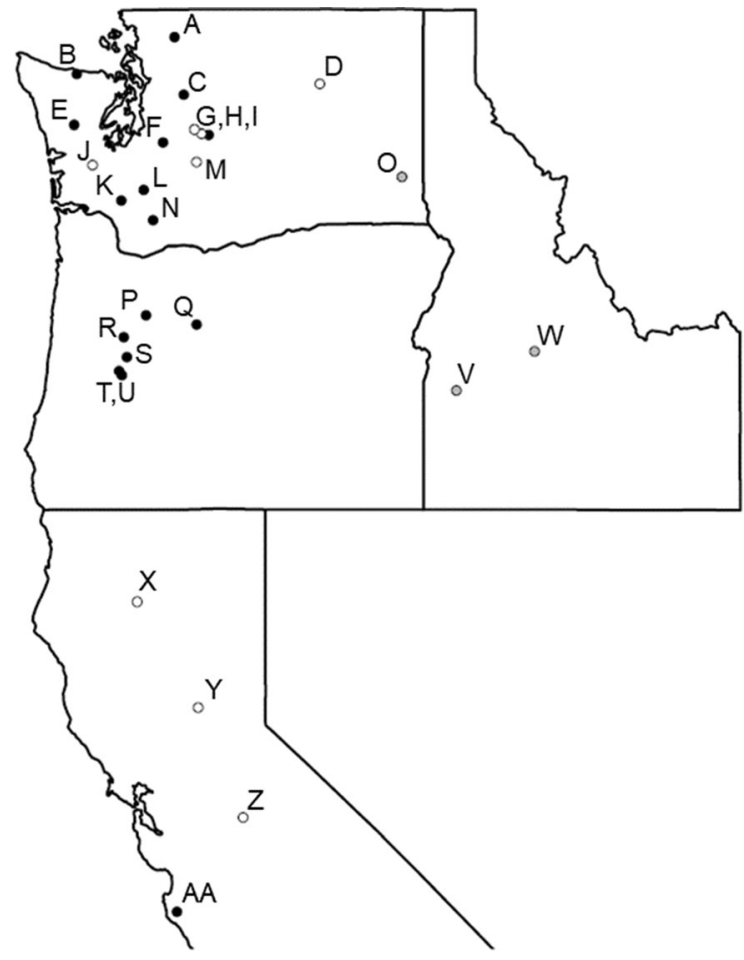

Fig. 3 Map of Washington, Oregon, Idaho and Northern California showing locations where trap-and-haul are currently operated (closed black circles), operated intermittently (closed grey circles), or being considered for future operations (open circles). Locations in Washington include the Baker River (A), Elwha River (B), South Fork Skykomish River (C), Upper Columbia River (D), North Fork Skokomish River (E), White River (F), Keechelus (G), Kachess $(\mathrm{H})$, and Cle Elum (I) reservoirs on the Yakima River, Wynoochee River (J), Cowlitz River (K), North Fork Toutle River (L), Bumping River (M), Lower Granite Dam (O), and Lewis River (N). Locations in Oregon include the North Santiam River (P), Deschutes River (Q), South Santiam River (R), McKenzie River (S), Fall Creek (T), and Middle Fork Willamette River (U). Locations in Idaho include Eagle Hatchery (V), and Redfish Lake (W). Locations in California include the Upper Sacramento River (X), Yuba River (Y), Tuolumne River (Z), and Carmel River (AA)

\section{Baker River, Washington}

The Baker River trap-and-haul program, which began transporting adult salmonids in 1925 after Lower Baker Dam (river kilometer [rkm] 2; height $=87 \mathrm{~m}$ ) was constructed, is operated to maintain anadromous fish populations upstream of impassable dams in the system. Juvenile collectors began operating at Lower Baker Dam in 1958 and at Upper Baker Dam (rkm 15; height $=95 \mathrm{~m}$ ) in 1960 (Table 1). The juvenile facilities were modified to improve collection efficiencies over time and were eventually replaced with state-of-the-art floating surface collectors in 2008 (Upper Baker Dam) and 2013 (Lower Baker Dam). Studies conducted to estimate collection efficiencies of the Baker River collectors have shown that $\sim 85 \%$ of juvenile sockeye salmon and $\sim 91 \%$ of coho salmon $O$. kisutch are collected and transported downstream of Lower Baker Dam (Kock et al. 2019a). The adult collection facility, located downstream of Lower Baker Dam, has also evolved over time, with the latest facility completed in 2010 . Collected adults are transported and released upstream of Upper Baker Dam or taken to hatcheries for spawning. Numerous fish species are collected at juvenile and adult collectors in the Baker River system, but transport is limited to sockeye salmon, coho salmon and cutthroat trout $O$. clarkii. Collectively, improvements to trap-and-haul facilities and hatchery supplementation have resulted in large increases in adult returns over time (personal communication, Nick Verretto, Puget Sound Energy).

\section{Cowlitz River, Washington}

In the Cowlitz River basin, upstream passage of anadromous fish was blocked in 1968 by the construction of Mossyrock Dam (rkm 105; height $=185$ $\mathrm{m})$, that lacks fish passage. Resource managers implemented a trap-and-haul program in the mid1990s (Table 1) to reintroduce Chinook salmon, steelhead, coho salmon, and cutthroat trout to the upper basin. This timing was based, in part, on the construction of Cowlitz Falls Dam (rkm 142; height = $43 \mathrm{~m}$ ) in the early 1990s, the uppermost dam in the system. Cowlitz Falls Dam was constructed with a surface collection system designed for juvenile salmonids. The original system collected downstream migrants during 1996-2016 and a new, larger system was added in 2017. Collected individuals are transported downstream $\sim 45 \mathrm{~min}$ and released below the lowest dam in the complex, Mayfield Dam (height = $76 \mathrm{~m}$ ), near the adult collection facility. At this site adult salmonids are collected and transported upstream to one of four locations: the Tilton River ( $30 \mathrm{~min}$ transport time), Lake Scanewa, the impoundment created by Cowlitz Falls Dam ( $\sim 45 \mathrm{~min}$ ), the Cowlitz River near the town of Packwood, Washington ( $90 \mathrm{~min})$, and the Cispus River upstream of Lake Scanewa ( $\sim 90 \mathrm{~min})$. The 
trap-and-haul program has successfully re-established anadromous fish populations in the upper Cowlitz River basin, and current efforts are focused on increasing populations to a level where stocks are healthy and harvestable (personal communication, John Serl, WDFW).

\section{Lewis River, Washington}

Three dams were constructed on the North Fork Lewis River during 1932-1958, blocking anadromous fish from accessing historical spawning habitat in the upper watershed. Efforts to reintroduce winter steelhead, spring-run Chinook salmon, and coho salmon upstream of the Lewis River dams began with an upstream (one-way) trap-and-haul program in 2012. Adult salmon and steelhead were collected in an existing fish trap at Merwin Dam (rkm 31; height = $98 \mathrm{~m}$ ), the downstream-most dam on the North Fork Lewis River. The fish trap was replaced with a new upstream collection and sorting facility in 2013. Once collected, anadromous adults are loaded onto fish hauling trucks and transported $\sim 60$ min to a release site upstream of Swift Reservoir, the upstream-most reservoir on the North Fork Lewis River. Juveniles, produced by transported adults, move downstream through Swift Reservoir and arrive at Swift Dam (rkm 77 ; height $=156 \mathrm{~m}$ ) where they can be collected in a floating surface collector that began operating in 2012. Collected juveniles are trucked $\sim 45 \mathrm{~min}$ to a release site located downstream of Merwin Dam. Recent adult returns to the Merwin trap suggest that many of these juveniles survive, enter the ocean, and eventually return to the Lewis River: $54 \%$ of the early-run coho salmon collected in 2017 were of natural-origin, up from 35\% in 2016 and $7 \%$ in 2015 (PacifiCorp 2018). Natural-origin fish collected at Merwin Dam originated upstream of Swift Dam and thus are products of the trap-and-haul program (PacifiCorp 2018). A total of 17,551 adult fish were captured in the trap in 2017, and 8569 of these were transported upstream while the others were taken to the hatchery (PacifiCorp 2018).

\section{Deschutes River, Oregon}

The Pelton Round Butte Hydroelectric Project was constructed on the Deschutes River during 1957-1964 and included both upstream and downstream passage facilities. However, the downstream facilities were ineffective at providing fish passage, primarily because fish failed to locate the collection facility, presumably due to complex water currents in the reservoir that failed to promote high discovery rates by outmigrants; facility use was abandoned in 1968. Thus, anadromous fish were excluded from the upper Deschutes River basin for nearly 4 decades until reintroduction efforts began in 2007 with releases of summer-run steelhead fry upstream of Round Butte Dam (rkm 166). In 2009, a new downstream collection facility began operating at the dam. Collected fish are transported downstream of Pelton Dam (rkm 155; height $=62 \mathrm{~m}$ ) and released into the Deschutes River. In 2012, returning adults were collected in the adult trap downstream of Pelton Dam and the two-way trapand-haul program became fully functional. Transport time for upstream and downstream migrants is $\sim 45$ min. Juvenile collection at Round Butte Dam peaked recently with a total of 933,896 fish in 2017 (PGE 2018). However, the number of adults transported upstream has remained low. For example, a total of 20 adult Chinook salmon and 30 adult steelhead were transported upstream in 2017 (PGE 2018). Although self-sustaining anadromous fish populations have not yet established upstream of the Pelton Round Butte Hydroelectric Project, efforts continue in the basin to reach this goal.

\section{North Fork Skokomish River, Washington}

On the North Fork Skokomish River, anadromous salmonid runs were severely affected by the construction of Cushman Dam No. $1(\mathrm{rkm} 32$; height $=84 \mathrm{~m})$ and No. $2(\mathrm{rkm} 28$; height $=72 \mathrm{~m})$ in the 1920s and 1930s. These dams did not include fish passage until 2014 and 2015 when adult collection and juvenile surface collection systems were installed at Cushman Dam No. 2 and No. 1, respectively. These installations facilitated plans to reintroduce and restore anadromous fish upstream. A floating surface collector began operating in 2015 with assessment of collection performance using experimental releases of juvenile coho salmon and sockeye salmon (from the Baker River project) upstream of Cushman Dam No. 1 (Tacoma Power 2016a, 2017). Collected juveniles are loaded onto trucks and transported $\sim 20$ min downstream where they are released below Cushman Dam No. 2. Reintroduction efforts have not proceeded to the point where adults are transported and released 
upstream of Cushman Dam No. 1, although testing of collection efficiency at the adult facility at Cushman No. 2 is ongoing (Tacoma Power 2016b).

\section{Intermittent use of trap-and-haul}

In some situations, trap-and-haul is used intermittently to rescue fish from perilous conditions or to jumpstart recovery efforts. Three examples are provided from the Snake River, Washington-Idaho, the Elwha River, Washington, and the Carmel River, California.

\section{Snake River-Salmon River, Washington-Idaho}

Snake River sockeye salmon no longer encounter impassable dams during their migration (Waples et al. 1991), but adult trap-and-haul is an important conservation strategy that has been used to protect the population from extinction. By the late 1980s, the Snake River sockeye salmon population had declined to a perilous level and were listed as endangered under the U.S. Endangered Species Act (NMFS 1991). This population exists solely within the Sawtooth Valley basin, Idaho, and is supported by a conservation broodstock program (Kozfkay et al. 2019). Anadromous adults that return to the Sawtooth Valley are trapped at one of two locations. In years of low returns all trapped adult fish are transported by truck to the conservation facility, Eagle Fish Hatchery, approximately 3.5 h away (Fig. 3; Baker et al. 2017). In years when the run size is larger (several hundred fish) a portion of the fish are transported to Eagle Fish Hatchery and others are moved upstream of the traps and allowed to naturally spawn. In relatively high abundance years, the number of fish transported to the hatchery often exceeds the brood requirements at the hatchery, and any excess fish at the hatchery are transported back to the Sawtooth Valley and released for spawning (personal communication, Dan Baker, Idaho Fish and Game). Trap-and-haul has also been used as an emergency procedure in years when conditions along the migration corridor are poor and there is potential for high mortality of adult sockeye salmon (Keefer et al. 2008a; Kozfkay et al. 2017). For example, Columbia, Snake, and Salmon river water temperatures in 2015 were exceptionally high in June and July, coincident with adult sockeye salmon migration through the system (NOAA 2015). In response to high temperatures, fishery managers implemented trap-and-haul operations and collected 51 adult sockeye salmon at an adult trap located in the Lower Granite Dam (rkm 173; height = 30 m; Fig. 1) fish ladder on the Snake River, Washington. The fish were transported around warm water conditions in the free-flowing portions of the Snake and Salmon rivers directly to Eagle Fish Hatchery in southern Idaho (average transport time $=8.3 \mathrm{~h}$ ), with no mortalities occurring during trapping and transport (NOAA 2015). Fish were transported by truck in two $946 \mathrm{~L}$ transport tanks with continuous oxygen flow and a water recirculating pump (Kozfkay et al. 2017). Cubed ice was placed in the tank partway through transport to temper the water from $\sim 17^{\circ} \mathrm{C}$ at Lower Granite Dam to $\sim 13{ }^{\circ} \mathrm{C}$ at Eagle Fish Hatchery (NOAA 2015). That same year an additional 24 PIT-tagged fish passed Lower Granite Dam and moved upstream volitionally, but only 7 (29\%) of those fish survived and arrived in the Sawtooth Valley (NOAA 2015). The Snake River sockeye salmon example suggests that applying trap-and-haul intermittently can be an important conservation strategy to protect at-risk populations from extreme environmental conditions or to support broodstock collection, even when it requires long transport distances and times during summer.

\section{Elwha River, Washington}

Two dams were breached on the Elwha River in 2012 to restore anadromous salmonid populations in the system. The river historically supported runs of Chinook salmon, coho salmon, sockeye salmon, pink salmon, chum salmon and steelhead, and researchers have been monitoring how fish recolonize the newly accessible habitat since the dams were removed. Resource managers implemented trap-and-haul of excess hatchery-origin coho salmon during 2011-2017 (Liermann et al. 2017; McHenry et al. 2018) because coho salmon exhibit low straying rates (Pess 2009), potentially limiting the rate at which they could recolonize areas upstream of the former dams. Researchers found that transported hatchery-origin coho salmon successfully spawned in novel habitats they were released into and produced outmigrating progeny at comparable rates to other populations in the region (Liermann et al. 2017). The authors also reported that more than half of the spawning adults 
observed during later study years were not fish that had been transported and concluded that these were progeny from adults transported in previous years that were returning to their natal sites (Liermann et al. 2017). The Elwha example suggests trap-and-haul can be used to kickstart reintroduction efforts in rivers affected by impoundments.

\section{Carmel River, California}

The steelhead population in the Carmel River has experienced dramatic declines over several decades due to several factors including dam construction and extended drought (Arriaza et al. 2017). Efforts to recover the population have included dam removal (San Clemente Dam in 2015), habitat restoration, and habitat and fish interventions to minimize mortality and increase steelhead dispersal in the system. Trapand-haul has been a key element in these efforts. Since 1989, juvenile steelhead have been collected and removed from stream reaches where water levels become critically low during May-October and are reared in a hatchery for later release or transferred to reaches where water levels are sufficiently high to allow volitional upstream and downstream movement. Additionally, trap-and-haul has been used to rescue upstream- and downstream-migrating adult steelhead that become stranded due to low water levels. These fish are typically transported to the ocean and released (Arriaza et al. 2017).

Summary of existing trap-and-haul programs

Our review of 17 existing trap-and-haul programs (Table 1) indicates these are being operated to achieve a broad range of management goals. Many are being operated experimentally as one of several management actions aimed at maintaining or improving salmon and steelhead populations in a given basin and some are operated intermittently as conditions dictate. Several programs are providing fish access to areas located upstream of impassable dams as an interim measure, prior to completion of downstream passage facilities that may eventually allow full implementation of population recovery efforts. In some cases, trap-and-haul is being used to provide access to areas located upstream of a natural passage barrier, to provide passage to areas blocked due to a natural disaster, and to limit exposure by endangered fish to dangerous in-river conditions.

\section{Design and operation of trap-and-haul facilities}

In this section, we summarize the substantial amount of knowledge that exists for design and operation of trap-and-haul facilities to provide a general understanding for readers outside the community of trapand-haul practitioners. We present information on adult facilities followed by juvenile facilities in cases where both are discussed. In several cases we provide information about various performance metrics of trap-and-haul programs (e.g., trap collection efficiency and prespawn mortality rate). There are many similarities between volitional passage facilities and trap-and-haul facilities, such as post-passage effects, fallback downstream over a dam after release, stress, low trap effectiveness, and migration delay. While these issues exist for both volitional passage and trapand-haul facilities, providing a direct comparison between the two approaches to passing salmonids at migration barriers was beyond the scope of our review.

Fish traps and collection facilities

Several studies have described fish traps or collection facilities for adult salmonids (Harmon 2003; Keefer et al. 2004, 2005; Morrisett et al. 2018) and existing guidelines are available for trap construction and operation (e.g., NMFS 2011). Furthermore, extensive information useful for designing these facilities is available from studies of fishways and other passage devices (e.g., Clay 1995; Haro et al. 1998, 2004; Noonan et al. 2012; Williams et al. 2012; Fjelstad et al. 2018). Several of the cited studies have emphasized the importance of siting and design of fishway entrances. Clay (1995), for example, described the entrance as the "most important single part of any fishway", and the same is likely true for adult collection facilities. To ensure that discovery rates are high, the collector entrance should either have a substantial volume of flow (relative to other discharge sources) or be placed at a location where fish naturally congregate in response to hydraulic or other navigation cues (Clay 1995; Williams et al. 2012; Fjelstad et al. 2018). NOAA (2014) recommended that attraction flow be directed perpendicular to the flow of the 
river if the attraction volume is low relative to the river volume, and that attraction flow be directed parallel to the river if attraction volume is relatively large. The source of attraction flow can be extremely important because some sources may contain different olfactory cues or have a different thermal profile than water in a dam tailrace (e.g., Caudill et al. 2013). Potentially confusing cues or physiochemical variation among water sources may cause fish to delay or reject entry into a collector or fishway.

In some cases, the collector entrance is located at a river level where fish enter a trap directly. For example, on the North Fork Skokomish River, the adult fish trap is immediately downstream from Cushman Dam No. 2, and fish can move directly from the dam's tailrace into the trap's holding pool. Collected fish are crowded into a hopper and raised to the top of the dam via a tram and jib crane, where they can be processed at the fish sorting facility (Tacoma Power 2016b). However, many adult collectors require fish to enter and ascend a fishway prior to entering a trap (e.g., collection facilities in the Cowlitz, Lewis, and South Santiam rivers). At these locations, conditions must promote discovery of the entrance and entry into the fishway opening(s), upstream movement through the fishway, and trap entry.

Trap designs include features to help retain fish after entry such as finger weirs (North Fork Toutle River), false weirs (McCutcheon et al. 1994), or Fykestyle entrances (Tacoma Power 2016b; PacifiCorp 2018). The latter are vertical V-shaped entrances with the widest part of the opening located at the downstream end of the entrance, which allows fish to guide along the narrowing entrance as they move upstream. Fyke-style openings are wide enough to allow trap entry but narrow enough that fish have a low probability of rediscovering the entrance and moving out of the holding pool and downstream. At other locations, such as the barrier dam on the Cowlitz River, the ladder exit is located at a higher elevation than the holding pool (i.e., a false weir), so passing fish drop into the holding pool and are retained.

Creating effective downstream fish passage at dams is a challenging task that can be influenced by a variety of factors including type of dam, reservoir size and thermal regimes, fish behavior, and differences in behavior among species. At run-of-river projects where reservoir storage capacities are limited and forebays fluctuate over a relatively narrow range, water is typically passed through multiple routes (e.g., turbines, spillways, sluiceways, fish bypasses) during seasons when juvenile salmonids are outmigrating. When multiple routes are available for downstream fish passage, fish residence time in a forebay may be reduced (Venditti et al. 2000). However, fish injury and mortality rates can vary considerably among passage routes (e.g., Coutant and Whitney 2000; Bickford and Skalski 2000; Muir et al. 2001; Pracheil et al. 2016); risk tradeoffs (i.e., between passage delay and mortality risk) are therefore common at such facilities. At water storage and flood-control projects, large fluctuations in reservoir water elevations present several challenges to downstream passage, including changes in the availability of downstream passage routes and potentially forced passage via more hazardous routes such as turbines (e.g., Coutant and Whitney 2000; Schilt 2007; Keefer et al. 2012, 2013).

Downstream passage and collection systems also must account for behavioral differences between species and life history types. For example, yearling Chinook salmon and steelhead undergoing smoltification generally exhibit directed outmigration behavior and move downstream quickly, typically in spring when river flows peak, and water temperatures are cool (Achord et al. 2007; Scheuerell et al. 2009; Bourret et al. 2016). Conversely, subyearling Chinook salmon often spend time rearing in the migration corridor and therefore move downstream more slowly than yearlings (e.g., Tiffan et al. 2000, 2012; Venditti et al. 2000; Schroeder et al. 2016). The oftenprotracted migration window of subyearlings may include periods when reservoir surface water temperatures are warm and downstream passage options at dams are limited. An example of this life history occurs in the Willamette River basin, where juvenile Chinook salmon exhibit a continuum of life histories that include groups of fish that outmigrate as fry, as subyearling smolts, and as yearling smolts (Schroeder et al. 2016). Consequently, outmigration occurs during most months of the year, and migrants can differ substantively in size and behavior. Behavioral differences are also common among populations and among life history types of Pacific salmon species (Quinn 2005; Hillgruber and Zimmerman 2009). For example, chum and pink salmon juveniles outmigrate within weeks of hatching, coho salmon and sockeye salmon primarily outmigrate during their second year of life, 
Chinook salmon outmigrate in their first or second year, and steelhead can rear in freshwater for 1-7 years before outmigrating (Quinn 2005).

At water storage projects where fish collection is needed, surface-oriented systems are used to capture juvenile salmonids in dam forebays for downstream transport in several existing trap-and-haul programs (Fig. 1). These devices were first used in the 1950s and 1960s in attempts to collect outmigrants in large water storage reservoirs in the Pacific Northwest (Fish Commission of the State of Oregon 1960; Collins and Elling 1964; Sweeney et al. 2007). The original surface collectors, often termed "gulpers", were operated using inflows of $\sim 4.2 \mathrm{~m}^{3} / \mathrm{s}$ or less and by most accounts the systems collected few fish. However, the concept continued to be developed, and newer versions in the 2000s used inflows as high as $170 \mathrm{~m}^{3} / \mathrm{s}$ (Kock et al. 2019a). Several of the highvolume devices collect a high percentage of tagged outmigrants ( $>90 \%$; Kock et al. 2019a) while others have been far less effective $(<40 \%$; Fig. 4$)$. The development of surface collectors has continued, and new facilities are being designed at various locations (e.g., BOR 2016; USACE 2018). Surface collectors have been designed to capitalize on the tendency for many juvenile salmonids to migrate near the surface and follow the bulk flow as they attempt to pass a dam (Johnson and Dauble 2006; Sweeney et al. 2007). Supplement 2 in Kock et al. (2019a) provides a detailed description of the various components of current state-of-the-art surface collection systems.

Head-of-reservoir collection (Fig. 1) is currently being considered at several sites where in-reservoir conditions are thought to limit the number of juvenile outmigrants that survive, move downstream, and enter a dam forebay for potential collection (Liedtke et al. 2010; Clancey et al. 2017; Kock et al. 2019b). Headof-reservoir systems may be effective in reservoirs that are very large, have complex bathymetry or hydrology, or lack velocity cues needed for juvenile salmonids to successfully orient and move downstream (e.g., Shasta Reservoir on the Sacramento River, California; Clancey et al. 2017). Such systems may also be appropriate in reservoirs with large populations of piscivorous fishes that can substantially reduce survival of downstream migrants, as in Lookout Point Reservoir on the Middle Fork Willamette River (Kock et al. 2019b) and in Fall Creek Reservoir (Murphy et al. 2019). Development and testing of

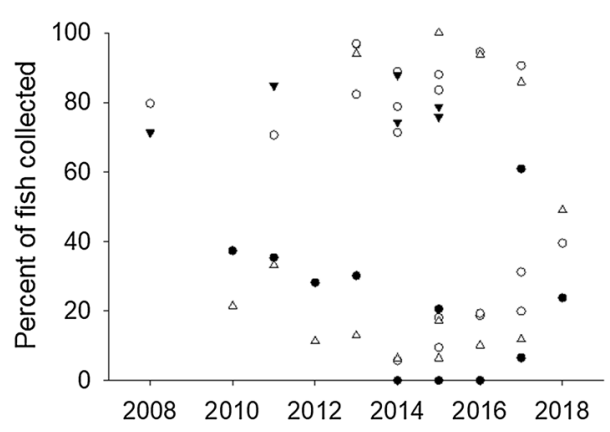

Fig. 4 Collection efficiency estimates for juvenile Chinook salmon (filled circles), coho salmon (open circles), sockeye salmon (filled triangles), and steelhead (open triangles) at surface collectors in Washington and Oregon, 2008-2018. Data obtained from annual reports from various locations described in this paper

head-of-reservoir collection systems is an emerging research topic in trap-and-haul science (Liedtke et al. 2010; Clancey et al. 2017). The survival benefits for juveniles transported past reservoirs and dams are potentially substantial, but there are not currently any operational head-of-reservoir collection systems and no data are available to assess the efficacy of this approach.

\section{Guidance systems}

Systems that guide fish towards collection entrances (Scruton et al. 2003; Nestler et al. 2008; ) or away from dangerous passage routes or undesirable locations (Schilt 2007; Kock et al. 2009; Perry et al. 2014; Hansen et al. 2019) have received considerable attention in the primary literature. Effective guidance systems have enhanced collection at many juvenile and adult collection facilities, including at several of the trap-and-haul case study sites (e.g., on the Baker, Lewis, and North Fork Skokomish rivers). Commonly used physical guidance structures such as nets or walls direct fish towards collection entrances to facilitate discovery rates and minimize passage delay (Adams et al. 2001; Johnson et al. 2005; Kock et al. 2019a). At several locations, suspended vertical net guidance systems are used to restrict downstream migrants from passing through alternate routes and to guide fish to collector entrances (Kock et al. 2019a). Net systems are used on some forebay collectors to funnel fish to the collector entrance ("guide nets"), decrease the likelihood of fish turning around inside the collector ("lead nets"), and prevent fish from passing the dam 
via alternate routes ("exclusion nets"; Kock et al. 2019a). Non-physical guidance systems have used sound, light, electricity, or aeration (i.e., bubble screens) to repel fish from locations where passage conditions are dangerous, such as through turbines or into water diversion intakes (Feist and Anderson 1991; Schilt 2007; Perry et al. 2014). Non-physical systems are attractive because they have the potential to affect fish movements without obstructing water flow, but their effectiveness is questionable. In some cases, these systems have produced unintended results such as increasing passage rates through dangerous passage routes (Schilt et al. 2007; Kock et al. 2009) and may be most effective if used in combination (e.g., strobe lights, sound, and bubble screens; Perry et al. 2014).

\section{Collection efficiency of fish facilities}

Collection efficiency of adult fish traps has been empirically evaluated at some locations and observations from other sites are useful for understanding factors that may reduce collection success. At Merwin Dam on the Lewis River, the adult trap was evaluated in 2015-2017 and two metrics were calculated: trap entrance efficiency, defined as the proportion of tagged fish that entered the trap of all tagged fish that entered the dam tailrace; and trap collection efficiency, defined as the proportion of tagged fish collected of all tagged fish that entered the dam tailrace (PacifiCorp 2018). Mean annual trap entrance efficiency estimates were $87.5 \%$ for winter-run steelhead (total $n=446$ tagged, 3 years), $46.5 \%$ for coho salmon (total $n=184,2$ years), and $90.0 \%$ for Chinook salmon (total $n=40,1$ year); mean annual trap collection efficiencies were $70.1 \%$ (winter-run steelhead), 36.2\% (coho salmon), and 38.0\% (Chinook salmon) (PacifiCorp 2018). The results from the Merwin Dam study illustrate the variability in adult trapping efficiency among species and that low collection rates may be an impediment to achieving some management goals. The data are being used to inform physical and operational modifications to the Merwin adult fish trap to increase future trap collection performance.

The adult fish collection facility on the North Fork Toutle River was in a general state of disrepair after years of operating under high sediment loads in the system. Features of the collection facility such as the crowder and fish lift were not operational, and funding was not available for repairs or maintenance. Liedtke et al. (2013) radio-tagged 9 winter-run steelhead and 11 coho salmon collected in the adult trap and then released the tagged fish $\sim 6 \mathrm{rkm}$ downstream to evaluate collection efficiency. None of the coho salmon and $3(33 \%)$ of the steelhead were eventually recollected at the trap (Liedtke et al. 2013). Given the small sample sizes in this evaluation, the results are anecdotal, but they do indicate that trapping efficiency was apparently very low at the site. Despite the apparent low collection success at the facility, several hundred winter-run steelhead, coho salmon, and cutthroat trout have been collected each year and transported upstream, maintaining anadromous fish populations in the river.

Adult trap collection efficiency was estimated at Foster Dam on the South Santiam River using a similarly small sample $(n=17)$ of hatchery-origin Chinook salmon in 2017 (M. L. Keefer, unpublished data). The fish were collected and tagged at a temporary trap $\sim 27 \mathrm{~km}$ downstream from Foster Dam (i.e., they were naïve to the Foster adult fish collection facility). All 17 salmon moved upstream and were detected in the Foster Dam tailrace, 16 (94\%) entered the Foster fishway one or more times, but only $7(44 \%)$ were eventually collected in the trap. The low collection efficiency in the radiotelemetry study affirmed observations by fish managers and researchers of low adult collection at the Foster facility. The behaviors did not appear to be related to hydraulic or structural features of the fishway or trap, which were recently rebuilt using established specifications (NMFS 2011), but instead may have been related to confusing olfactory or temperature cues. Water for the facility is drawn from deep within Foster Reservoir and large $\left(4-8{ }^{\circ} \mathrm{C}\right)$ temperature gradients can occur between the South Santiam River, the Foster Dam tailrace, and the collection facility (M. L. Keefer, unpublished data). The circumstances surrounding these apparently low collection rates at the Foster adult fish collection facility highlight the need for postconstruction evaluations and adaptive management at these types of facilities.

Where reservoir surface collectors are used to collect downstream migrants, fish collection efficiency estimates have been obtained in numerous telemetry studies and results have varied substantially by site, year, species, and life history stage (Fig. 4; also see Al-Chokhachy et al. 2018; Kock et al. 2019a). 
Surface collectors at dams on the Baker and Clackamas rivers have collected $75-98 \%$ of the tagged fish released during collection efficiency studies (Kock et al. 2019a). These facilities are operated using high inflow $\left(14.2-35.4 \mathrm{~m}^{3} / \mathrm{s}\right)$ in relatively small forebays (7-49 ha). At other locations (e.g., Cushman Dam No. 1 on the Skokomish River and Swift Dam on the Lewis River) collection efficiencies have been much lower, ranging from 3 to $30 \%$ (PacifiCorp 2019; Tacoma Power 2017). The Cushman and Swift facilities are operated using lower inflow $\left(7.1-17.0 \mathrm{~m}^{3} / \mathrm{s}\right)$ in large forebays (81-149 ha), compared to surface collectors on the Baker and Clackamas rivers. Other recent studies have shown that surface collector modifications (e.g., reducing noise produced by pumps at Swift Dam on the Lewis River; PacifiCorp 2019) or operational alterations (e.g., extended periods of constant inflow at Round Butte Dam on the Deschutes River; PGE 2018) can substantially improve collection efficiency. Several existing surface collectors (see previous section "Downstream trap-and-haul") have been operated for short periods ( $<5$ years), and collection efficiency improvements will likely be realized in coming years as operators become familiar with each system and modify structures or operations to adapt to the local environmental and biological circumstances.

Results from a recent meta-analysis of surface collectors by Kock et al. (2019a) showed that inflow volume, fish guidance net presence, and size of the collector entrance positively affected collection efficiency, and that effective forebay area (i.e., the size of the forebay that fish can access) was inversely associated with collection. There is also emerging information that suggests factors such as excessive noise caused by surface collector pumps may limit collection success (PacifiCorp 2019). Kock et al. (2019a) reported steelhead had the highest collection efficiencies, on average, across projects and Chinook salmon had the lowest collection efficiencies among species studied (steelhead, coho salmon, sockeye salmon, and Chinook salmon). These differences may be due, in part, to differences in migration timing, vertical distribution, or physiological readiness to migrate. For example, subyearling Chinook salmon move downstream in summer in some rivers when reservoir surface water temperatures are high, and then reside deep in the water column where cooler water is available. These populations, even when physiologically prepared to migrate downstream, may not be susceptible to surface collection during periods of thermal stratification (Fig. 5; also see Beeman et al. 2016a).

Sorting and holding

Fish sorting is an important element in most adult trapand-haul programs. Sorting can be used to remove non-target fish or species (e.g., hatchery-origin fish or non-native species) from the transported population, collect scale or genetic samples to assess age structure or monitor reproductive success (Sard et al. 2015, 2016), mark or tag fish to monitor behavior and survival after fish are released (Keefer et al. 2010; DeWeber et al. 2017; Naughton et al. 2018; Kock et al. 2018a), and distribute fish in accordance with management strategies and regulatory requirements. Most adult fish collection facilities were designed with sampling stations integrated into the infrastructure of the collection facility. Various methods of anesthesia (carbon dioxide, electro-anesthesia, isoeugenol, etc.) have been used to sedate fish for handling at these facilities. Many of the guidelines for adult trapping systems and fish handling and sampling include considerations for factors such as fish density, fish size, and water temperature (NMFS 2011). Holding pools at trap-and-haul facilities should be designed to provide safe conditions where fish can be held for short periods (24-96 h) prior to transport. NMFS (2011) provides criteria for factors such as holding

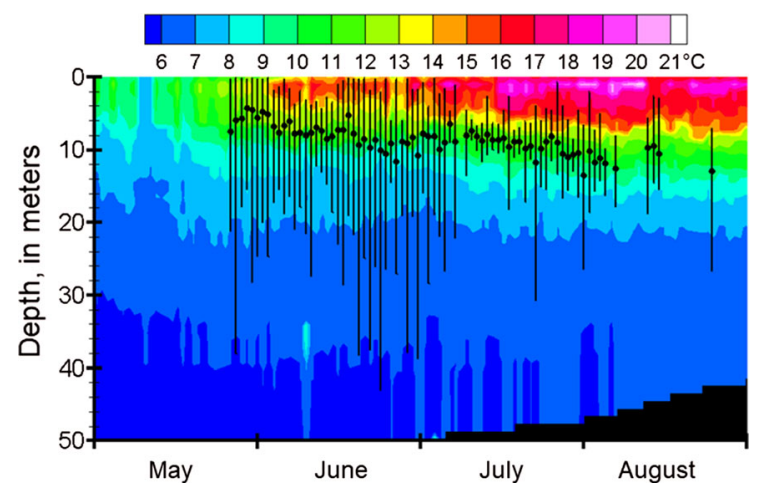

Fig. 5 Graph showing mean daily depths (black dots) and ranges (error bars) of acoustic-tagged subyearling Chinook salmon within $20 \mathrm{~m}$ (horizontal distance) of a surface collector entrance (3.7 m deep) in the forebay of Cougar Dam, South Fork McKenzie River, Oregon, 2014. Legend at top shows water temperature. Figure reprinted from Beeman et al. (2016a) 
pool capacity under a range of water temperatures, holding pool inflow, and minimum water depth of the holding pool. The document also includes suggestions for structures that can be used to provide shade and minimize adult jumping, which can lead to fish injury or mortality during holding.

Following collection in a surface-oriented system, juvenile salmonids are often conveyed to a fish holding facility where they can be sampled or held. Most systems pass juveniles through a series of separator bars that sort fish by size. Size separation is typically justified by a need to prevent predation of small fish by larger fish during holding. Smolt-sized fish are often retained for downstream transport while fry- and parr-sized fish (i.e., non-migrants such as sockeye salmon fry that are incidentally captured) may be either transported downstream (e.g., Upper Baker Dam on the Baker River, Swift Dam on the Lewis River) or returned to the reservoir to continue rearing (e.g., Cowlitz Falls Dam on the Cowlitz River, Round Butte Dam on the Deschutes River). Sampling of collected juveniles varies among projects. At some locations, biological data are collected for all fish or all are marked or tagged. At other locations, a portion of the catch is sampled, and non-sampled fish are directly transferred to holding tanks or raceways. NMFS (2011) criteria for juvenile holding tanks includes a minimum depth of $0.76-0.91 \mathrm{~m} \mathrm{(30-36} \mathrm{in)} \mathrm{and} \mathrm{an}$

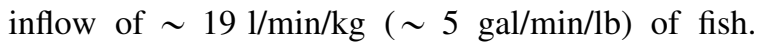
Juvenile salmonids are typically crowded into a hopper from holding tanks on the surface collection system as the first step in downstream transport. The hopper is lifted directly to a transport truck or is placed on a small barge or tramway that leads to a location where the hopper can be loaded onto the truck. Fish are transferred to a tank on the transport truck using waterto-water transfer.

\section{Transport and release}

A variety of approaches have been used to move adult salmonids from holding tanks or pools to vehicles for upstream transport. Several of the case study facilities described above were designed to limit handling during this process and to transfer fish using automated features such as crowders or fish lifts. Various lifting devices are used to load fish onto transport trucks including fish lift/hopper systems, and fish locks (NMFS 2011). At Cushman Dam No. 2 on the
North Fork Skokomish River, a fish lift/hopper system raises fish from the holding pool to an elevation where fish can be released into a tank on a transport truck (NMFS 2011). Similarly, a fish lock like the one at Merwin Dam on the Lewis River, is a mechanicalhydraulic system that raises fish in a water chamber or tower to an elevation where they can be processed or loaded onto a transport truck. At other locations (e.g., Baker River, Cowlitz River) holding pools are in large overhead structures under which transport trucks are driven and gravity-driven water-to-water transfer occurs. Some facilities require additional handling to move fish to transport trucks. For example, at Roza Dam on the Yakima River, fish are crowded from a holding pool into a distribution flume that leads to a sampling station where each fish is anesthetized and processed. After sampling, fish are inserted into a Whooshh Fish Transport System (Mesa et al. 2013; Fast et al. 2016; Geist et al. 2016; Kock et al. 2018a) that uses differential air pressure to move adults $12.2 \mathrm{~m}$ from the sampling station to the transport truck. On the North Fork Toutle River, transfer facilities are no longer operational, so fish are handnetted and carried to a sampling station where they are processed and then hand-loaded into transport trucks.

The transport of juvenile and adult salmonids from collection facilities to in-river release sites is relatively consistent among trap-and-haul programs. Fish are transported in trucks that can maintain dissolved oxygen levels in the transport tank at 6-7 ppm and maintain water temperature at the ambient level (NMFS 2011). It is recommended that transport tanks for hauling adult salmonids be "closed" systems with tanks filled to the maximum water level to reduce water sloshing that could kill or injure fish. Some trucks have baffles in the tank to reduce sloshing. As an example, a typical transport truck used in the Willamette River basin has a 56781 (1500 gal) uninsulated stainless-steel transport tank that contains two aerators, supplemental oxygen, and temperature and oxygen monitors (personal communication, Doug Garletts, USACE). For most of the trap-and-haul programs in Table 1, transport times range from 10 to $60 \mathrm{~min}$, but in some cases, fish are hauled for longer periods. Release sites used by the various trap-andhaul programs vary widely in terms of the number used and their locations within a basin. However, the fish release process is generally consistent. Transport trucks are positioned near the release site, a gravity- 
fed pipe is attached to the egress opening on the transport tank, the tank is opened, and fish pass through the pipe into the receiving water body. NMFS (2011) recommended that fish should not drop more than $1.8 \mathrm{~m}$ (6 ft) from the pipe to the water surface, the impact velocity should not exceed $7.6 \mathrm{~m} / \mathrm{s}(25 \mathrm{ft} / \mathrm{s})$, and the receiving water should be at least $0.9 \mathrm{~m}(3 \mathrm{ft})$ deep.

Factors such as loading time, hauling density, transport timing, and disease transfer have been evaluated at several locations with varying results. Colvin et al. (2018) evaluated factors affecting hauling mortality of adult spring-run Chinook salmon in the South Santiam River and Middle Fork of the Willamette River in 2006-2013. They found that fish loading time and hauling density were positively associated with hauling mortality but observed that these relationships varied between rivers and among years. The authors noted that trip-specific factors such as water quality, dissolved oxygen levels, and pathogen loads in the transport tank likely affected hauling mortality on a trip-by-trip basis.

Downstream transport of juveniles occurs daily during most of the fish collection season at most facilities. At some locations, daily collection numbers require multiple transport events each day during peak outmigration periods. Following transport, fish are typically released into holding ponds where they remain for at least $24 \mathrm{~h}$ to recover from handling stress associated with collection and transport. The holding ponds are often referred to as "stress relief ponds" and are typically located adjacent to the free-flowing river. NMFS (2011) requires all transported juvenile fish to be transferred to stress release ponds where they remain for at least $24 \mathrm{~h}$, and then be allowed to volitionally enter the river and resume downstream migration. If fish remain in the stress relief pond for $>48 \mathrm{~h}$, NMFS (2011) requires fish to be forced from the pond by crowding or draining of the pond.

Fish-handling that occurs during loading, transport, and release is a critical period in the trap-and-haul process because of the relationship between stress and fish health. Harmon (2009) conducted a review of transport methods to identify best practices for reducing stress and maintaining water quality in fish transport tanks. He reported that it was important to minimize potential stressors and the duration of exposure to those stressors to maximize transport survival rates. The review included methods for maintaining oxygen and water temperature at safe levels during transport, recommended the addition of salt (5-10\% solution; Moyle and Cech 1988; Mazic et al. 1991) to the transport water to minimize osmoregulatory stress for juveniles and adults, and summarized available information on water conditioners, anesthetics, acclimation, and carrying capacity.

\section{Biological responses to trap-and-haul}

Trap-and-haul programs and volitional fish passage facilities both have the potential to affect individual fish and fish populations through a variety of biological mechanisms. Many fish experience migration delays and stress during handling and passage events, which in turn can affect swimming performance, increase disease transmission rates and infection risks, and even lead to premature death. Adult fish that pass dams volitionally or are transported upstream may fall back past the dams (Boggs et al. 2004; Naughton et al. 2018) or fail to locate spawning habitat, and not contribute to population productivity. Similarly, juvenile fish that use fish bypass systems or are transported may be injured or infected in these systems. Transported fish have an additional risk of elevated stray rates as adults compared to fish that remain in-river during juvenile outmigration, resulting in decreased reproductive potential of the transported population (Keefer and Caudill 2014). We consider these factors and present information about what is known for trapand-haul in the following sections.

Migration delay and survival.

There is limited information on how trapping affects migration timing and survival in existing trap-and-haul programs, but several studies (e.g., Bromaghin et al. 2007; Marauskas et al. 2014; Morrisett et al. 2018) have evaluated these factors in other settings and provide useful insights. Murauskas et al. (2014) evaluated passage delay and blockage of adult sockeye salmon at a combined passage and trapping facility on the Wenatchee River, Washington, in 2008-2012. Trapping operations occurred 7 days per week in 2008-2010 and median passage delay ranged from 0.4 to 8.7 days while an estimated $8-38 \%$ of the returning adults were prevented from migrating upstream past the trap (Murauskas et al. 2014). After reducing trap operations to $<24 \mathrm{~h}$ per week in 
2011-2012 (fish were allowed to volitionally pass when the trap was not operating), the authors reported that median passage delay decreased to $6 \mathrm{~min}$ and nearly all adults migrated to the spawning grounds. Morrisett et al. (2018) evaluated how trapping at Lower Granite Dam affected in-ladder transit time and upstream homing success for Chinook salmon, sockeye salmon and steelhead in 2012-2016. The authors found that trapping delayed mean transit time through the fish ladder by $4-18 \mathrm{~h}$ and noted that fish delayed by $10 \mathrm{~h}$ or more had lower homing success than fish that freely passed through the fish ladder and were not routed to the trap. These examples illustrate the need to carefully consider how trap operations may affect fish behaviors and collection rates as well as posttransport effects in a trap-and-haul program.

\section{Handling effects}

Data from the Yakima River basin are useful for assessing the safety of transporting adult salmon. Spring-run Chinook salmon broodstock for the Cle Elum Supplementation and Research Facility (CESRF), operated by the Yakama Nation, are collected at Roza Dam each year. Adult Chinook salmon destined for the CESRF are PIT-tagged prior to transport, which allows researchers to monitor posttransport survival of adults to the time of spawning, and to track fecundity, fertilization success, and embryo survival rates after spawning occurs. Data collected in 2001-2018 showed $96.3 \%$ of the $>$ 10,000 adult Chinook salmon transported from Roza Dam to CESRF (about $60 \mathrm{~min}$ transport time) survived to spawning (data courtesy of Yakama Nation Fisheries). The high survival rates, over nearly 2 decades, indicate collection, handling, and transport of adult Chinook salmon can be safely accomplished under suitable conditions and have minimal effects on survival to the time of spawning.

Numerous in situ and laboratory studies have shown that fish trapping and handling can negatively affect physiological responses (e.g., those associated with the stress response) and whole organism performance (e.g., disease resistance, escape behavior, ability to enter saltwater, ability to imprint on olfactory cues, etc.) of both juvenile and adult salmonids (Specker and Schreck 1980; Schreck and Li 1985; Maule et al. 1988; Congleton et al. 2000). Schreck and $\mathrm{Li}$ (1985) found trapping of fish: (1) is stressful and severity of the stress varies seasonally; (2) is associated with recovery times of several days; (3) can lower swimming ability; and (4) result in cumulative stress due to exposure to various elements encountered sequentially in a collection facility. The trapping and holding environment affects stress levels of trapped fish. For example, juvenile Chinook salmon trapped during the day under darkened conditions appeared less stressed than those exposed to the sun, and exposure to high densities of other fish species was stressful during collection (Schreck and Li 1985). Thus, providing shade or creating darkened conditions in trapping and holding facilities, and minimizing holding densities, appear to be reasonable measures for minimizing stress. Schreck and Li (1985) found that loading juvenile fish into a transport vehicle appeared to be the most stressful aspect of the actual transport process and reported it took fish several days to recover. Stewart et al. (2017) found it could take juvenile salmon weeks to recover from the cumulative stress of capture and transport. Transporting juvenile salmon can have other effects such as lowered disease resistance, reduced ability for conditioning to an odorant, and failure to complete smoltification following transport and release (i.e., residualization; Schreck 1980). However, if conditions are good (i.e., good water quality, low fish density) and trip duration is appropriate, fish can partially recover from stress while a vehicle is en route to the release site (Schreck 1980, 1985). Results from these studies illustrate the need to carefully consider how fish are collected, held, and transported to minimize stress and its associated effects on fish health and performance.

In summary, the design and operation of trap-andhaul systems is critical for determining the amount of stress fish will incur during collection, transport and release. Stress endured during trap-and-haul may substantially affect fish performance and survival following release. Therefore, facility operations and handling procedures should aim to minimize severity and duration of stress. Here, we provide recommendations for measures to minimize stress based on personal experience with trap-and-haul operations and supported by a large body of research (Wedemeyer 1976; Schreck 1980; Schreck and Li 1985; Maule et al. 1988; Schreck et al. 1989, 1995, 1997, 2006; Benda et al. 2015; Schreck and Tort 2016; Cogliati et al. 2019): 
- Trap-and-haul operations should be designed to be fish-friendly and to minimize stressor exposure duration. Fish collection, transfer, holding and transport structures should not produce turbulent water conditions and should be free of sharp angles and edges that can cause injuries. Providing shade or creating darkened conditions, particularly in shallow water, can be beneficial. Water-to-water transfers are highly recommended because netting and direct handling induce high stress responses, especially if fish are dewatered. If netting is necessary, soft mesh should be used and nets with knotted twine should be avoided because the knots can cause skin injuries. Further, mesh should be appropriately sized for the fish being handled. If mesh size is too large for a particular size class of fish eye injuries and blindness can occur during netting because a fish's snout can pass through the mesh. Furthermore, overloading nets should be avoided because fish in the bottom of a full net can be crushed or injured. This is particularly problematic for small juveniles and sexually mature female adults.

- Overcrowding that negatively affects water quality in the holding and transport phases should be avoided. The severity of stressors in trap-and-haul can be reduced by minimizing the risk of infection with pathogenic organisms to optimize post release performance of fish. Minimizing cross infection can be accomplished by lowering fish density, elevating flow, and for many pathogens, maintaining cool water temperature. Treating fish with antibiotics to increase their survival after release is an option for consideration. Holding fish in a system that does not harbor necessary hosts of certain pathogens would eliminate the risk of further infection of these pathogens.

- The timing of specific operations should be considered as a measure that could limit stress. For example, juvenile releases that occur during dark evening hours when fish are prone to migration and less vulnerable to predators could be used to reduce stress and increase survival.

- Adding salt to transport water to approximate the physiological level of saline can help fish overcome osmoregulatory difficulties associated with stress and be beneficial in reducing the severity of the transport experience. Commercially available additives for transport water also help with disruption of the integrity of the skin caused by crowding and handling.

- Trap-and-haul programs often incorporate a fish tagging element into the process. From a stress management perspective, tagging should be done in such a way that the fish perceived it as part of some other stressful event (i.e., so the fish receives a single rather than two, sequential stressors). For example, fish could be tagged as part of the loading process, rather than separately before loading occurs.

- The effects of stress experienced during trap-andhaul is less severe if fish are released in locations where they can regain orientation without exposure to high-velocity currents that are energetically demanding. The release site should not contain substantial predator concentrations to allow sufficient time for fish to recover without facing the challenges of predation avoidance.

\section{Fallback}

The term "fallback" refers to the downstream movement, generally at a dam, by fish that would be expected to actively move upstream to locate potential spawning areas. Fallback has been observed and documented for a variety of Pacific salmon species (Reischel and Bjornn 2003; Boggs et al. 2004; Richins and Skalski 2018), Atlantic salmon (Salmo salar; Hagelin et al. 2016; Frechette et al. 2019), and alewives (Alosa pseudoharengus; Frank and Mather, 2009) among others. Fallback rates for Pacific salmon at mainstem dams on the Snake and Columbia rivers have been well documented (Reischel and Bjornn 2003; Boggs et al. 2004; Naughton et al. 2006), with annual run-specific estimates at individual dams ranging from 1.9 to $22.0 \%$ for adult Chinook salmon, sockeye salmon, and steelhead. Although high numbers of upstream migrants can fall back at dams with fishways, many of the fish eventually reascended the dam where fallback occurred and resumed upstream migration (Reischel and Bjornn 2003; Boggs et al. 2004; Naughton et al. 2006). Other fish remained downstream from the fallback location (e.g., Keefer et al. 2008b; Richins and Skalski 2018). Reascension is not an option for adult salmonids that fall back via spillways or turbines at most high-head dams. Most fallback fish at these sites are lost to the anadromous 
population upstream of the dam, although those that escape serious injury may potentially re-enter adult traps or spawn at downstream sites (Naughton et al. 2018).

In the Cowlitz River, Kock et al. (2016) reported fallback rates for transported adults ranging from 7 to $22 \%$ for natural-origin and hatchery-origin steelhead and Chinook salmon following released upstream (3.9 rkm) of Cowlitz Falls Dam during 2005-2009 and 2012. Fallback by hatchery-origin fish was lower for fish released at alternate release sites located farther upstream than the primary release location (Kock et al. 2016). Similarly, on the South Santiam River, Naughton et al. (2018) reported 14\% of tagged Chinook salmon released into Foster Reservoir fell back downstream of Foster Dam compared to $1 \%$ of tagged Chinook salmon released in the river upstream of Foster Reservoir. In 2017, Kock et al. (2018b) monitored behavior and movements of adult sockeye salmon after release upstream of Cle Elum Dam and found $20 \%$ of tagged fish moved downstream of the dam prior to spawning. On the Elwha River, fallback over a dam was not an option because the dams had been removed but McHenry et al. (2018) reported hatchery-origin coho salmon outplanted into the mainstem Elwha River fell back to a hatchery at a higher rate than fish outplanted into tributaries. Key takeaways from these findings are: (1) fallback rates can be substantial at locations where fish volitionally pass dams and at locations where trap-and-haul is used to move fish around dams; (2) fallback seems to occur for similar proportions (up to 25\%) of fish, regardless of how they pass dams; and (3) increasing the distance between release sites and the dam is a potential strategy for reducing fallback rates in trap-and-haul programs.

\section{Prespawn mortality}

Adult salmon can experience significant mortality during freshwater migration or when holding on the spawning grounds prior to spawning (Keefer et al. 2010; Hinch et al. 2012; Bowerman et al. 2016). The latter is termed "prespawn mortality" and it can be exacerbated by trap-and-haul programs due to stress during collection and transport (Benda et al. 2015; Colvin et al. 2018), and the fact that fish are released into an environment they did not volitionally enter. This section focuses on factors known to affect prespawn mortality in trap-and-haul programs, but readers should be aware that prespawn mortality occurs in systems where volitional passage is possible (Bowerman et al. 2016), as well as in undammed river systems with thriving salmon populations (Quinn et al. 2007).

Evaluation of prespawn mortality related to trapand-haul has received considerable attention in the Willamette River basin (Keefer et al. 2010; Benda et al. 2015; DeWeber et al. 2017; Bowerman et al. 2018; Colvin et al. 2018; Naughton et al. 2018). In the Middle Fork Willamette River, mean annual mortality of 30-60\% was reported for several transported groups of tagged Chinook salmon, and some release groups experienced $>90 \%$ mortality (Keefer et al. 2010; Naughton et al. 2018). In the South Santiam River, DeWeber et al. (2017) reported prespawn mortality rates were low $(\leq 13 \%)$ in $2009-2012$ but were very high (74\%) in 2013. Outside the Willamette River basin, Kock et al. (2018a) reported $8 \%$ of sockeye salmon that were transported upstream and released directly into Cle Elum Reservoir died prior to spawning in 2017.

Survival to spawning of trap-and-hauled adult salmonids can be highly variable among watersheds and among years (Keefer et al. 2010; DeWeber et al. 2017; Bowerman et al. 2018; Kock et al. 2019b). Variation in prespawn mortality may be in part explained by seasonal, annual, and watershed-scale variation in environmental conditions affecting infection and/or disease resistance rates, as prespawn mortality has frequently been associated with pathogens (Benda et al. 2015; Bowerman et al. 2016). Holding early-run fish in water of good quality and free of pathogens prior to transport may enhance survival (Benda et al. 2015). Survival of transported adults also appears to be negatively affected by the time it takes to load fish into trucks, fish density in the tank, timing of hauling trips, thermal exposure, and low instream flows at release sites (Colvin et al. 2018). Warm water temperature, in particular, appears to be an important driver of prespawn mortality (Keefer et al. 2010; Benda et al. 2015; Bowerman et al. 2018; Naughton et al. 2018). Spring-run Chinook salmon may be especially vulnerable due to their extended holding prior to spawning during the warmest (summertime) part of the year. This observation was supported by Benda et al. (2015) who showed that outplanted Chinook salmon were 12.6 times more 
likely to experience prespawn mortality than groups of Chinook salmon held at a hatchery facility in $13{ }^{\circ} \mathrm{C}$ water. Bowerman et al. (2018) observed that prespawn mortality rates were highly variable when average water temperature was in the $18-20{ }^{\circ} \mathrm{C}$ range, but that nearly all estimates of prespawn mortality exceeded $80 \%$ when mean water temperature was $>20^{\circ} \mathrm{C}$.

Other factors such as sex, fish origin, and transport protocols (i.e., timing, fish density) also affect prespawn mortality rates. Keefer et al. (2010) found that females had lower physical condition and higher prespawn mortality than male counterparts, while Bowerman et al. (2018) found prespawn mortality rates were positively correlated with the proportion of hatchery-origin fish on the spawning grounds. The adult Chinook salmon transport study by Colvin et al. (2018) indicated fish density and transport truck loading time were predictive of transport mortality. DeWeber et al. (2017) reported prespawn mortality decreased for groups of salmon hauled later in the season, but noted that other studies (e.g., Evans et al. 2015; Sard et al. 2015) have shown early-transport groups have higher rates of reproductive success. The mentioned studies, and others, have generally concluded that prespawn mortality is likely influenced by multiple additional factors, such as previous dam passage, fishing pressure, instream habitat, energetic status, and pathogen loads. Collectively, research on prespawn mortality suggests risks can be substantial in some circumstances, can vary widely even at single study sites, and causation can be difficult to conclusively establish.

\section{Reproductive success}

Research has shown that many transported adult salmonids survive and are reproductively successful upstream of impassable dams when trap-and-haul is used (Baumsteiger et al. 2008; Sard et al. 2015, 2016; Evans et al. 2016; Weigel et al. 2019). Baumsteiger et al. (2008) used parentage analysis to estimate the reproductive success of outplanted hatchery-origin Chinook salmon in Shitike Creek, Oregon in 2002 and 2003. They found hatchery-origin outplants produced juveniles from matings between outplanted males and females as well as from matings with natural-origin fish present in the stream. They also observed some outplanted males mated with up to seven females and some outplanted females mated with up to four males
(Baumsteiger et al. 2008). Evans et al. (2016) evaluated reproductive outcomes of transported hatcheryorigin and natural-origin Chinook salmon on the South Santiam River and found individuals had highly variable reproductive success with some fish producing as many as 40 adult progeny while others produced none. The authors also noted a possible trend towards reduced fitness in mate pairs from hatchery-origin and natural-origin fish which led them to conclude that use of natural-origin fish may improve population productivity in such programs. Weigel et al. (2019) evaluated steelhead spawning success in the South Santiam River and found that more than half of the fish outplanted in 2012-2016 produced either juvenile or adult offspring. Sard et al. (2015) found that factors such as release location and release date had inconsistent effects on the reproductive success of Chinook salmon in the South Fork McKenzie River and observed that origin had little effect. Reproductive success has been high enough to achieve cohort replacement in some locations (South Santiam River; Evans et al. 2016) but not others (South Fork McKenzie River; Sard et al. 2016).

Operations that minimize stress for fish are critical

The design and operation of trap-and-haul systems is critical for determining the amount of stress fish will incur during collection, transport and release. Stress endured during trap-and-haul can substantially affect fish performance and survival following release; facility operations and handling procedures should therefore aim to minimize the severity and duration of stress. In this section we provide recommendations for measures to minimize stress based on personal experience with trap-and-haul operations and supported by a large body of research (Wedemeyer 1976; Schreck 1980; Schreck and Li 1985; Maule et al. 1988; Schreck et al. 1989, 1995, 1997, 2006; Benda et al. 2015; Schreck and Tort 2016; Cogliati et al. 2019).

Trap-and-haul operations should be designed to be fish-friendly and to minimize stressor exposure duration. Fish collection, transfer, holding and transport structures should not produce turbulent water conditions, be free of sharp angles and edges that can cause injuries, and provide shade or darkened conditions, particularly in shallow water conditions. Water-towater transfers are highly recommended because netting and direct handling induce high stress 
responses, especially if fish are dewatered. If netting is necessary, soft mesh should be used and nets with knotted twine should be avoided because the knots can cause skin injuries. Further, mesh should be appropriately sized for the fish being handled; the use of mesh sizes too large for a particular size class of fish can lead to eye injuries and blindness because a fish's snout can pass through the mesh. Furthermore, overloading nets should be avoided because fish in the bottom of a full net can be crushed or injured. This is particularly problematic for small juveniles and sexually mature female adults.

Overcrowding that negatively affects water quality in the holding and transport phases should be avoided. The severity of stressors in trap-and-haul can be reduced by minimizing the risk of infection with pathogenic organisms to optimize post-release fish performance. Minimizing cross infection can be accomplished by lowering fish density, elevating flow, and for many pathogens, maintaining cool water temperature. Treating fish with antibiotics to increase their survival after release is an option for consideration. Holding fish in a system that does not harbor necessary hosts of certain pathogens would eliminate the risk of further infection by these pathogens.

The timing of specific operations should be considered as a measure that could limit stress. For example, juvenile releases that occur during evening hours when fish are prone to migration and less vulnerable to predators could be used to reduce stress and increase survival. The addition of additives, such as salt, to transport water can be beneficial in reducing the severity of the experience. Adding salt to approximately the level of physiological saline can help fish overcome osmoregulatory difficulties associated with stress. Commercially available additives for transport water help with disruption of the integrity of the skin caused by crowding and handling. Trap-and-haul programs often incorporate a fish tagging element into the process. From a stress management perspective, it would be desirable if the tagging process was done in such a way that the fish perceived it as part of some other stressful event (i.e., so the fish receives a single rather than two, sequential stressors). For example, fish could be tagged as part of the loading process, rather than separately, before loading occurs. The effects of stress experienced during trap-and-haul is less severe if fish are released in locations where they can regain orientation without exposure to heavy currents that are energetic demanding. The release site should not contain substantial predator concentrations to allow sufficient time for fish to recover without facing the challenges of avoiding predation.

Each trap-and-haul system is unique and within a given system day-to-day variation in stress experienced occurs (Schreck et al. 2006). The severity of stress experienced is a function of numerous variables including: (1) the general wellbeing of the fish as they enter a trapping system (e.g., are they already stressed or infected?); (2) how close other environmental variables are to being optimal for the species involved (e.g., water that is warmer than optimal can have an exponentially-increasing negative effect as it approaches tolerance levels); (3) the duration of each stressful element of trap-and-haul experienced (in general, the longer the exposure to a stressor, the exponentially greater the stress experienced); and (4) the cumulative effects of stressors of each element of trap-and-haul (e.g., traps can be injurious to fish, the loading of a transportation vehicle, and the release system and process can each be very stressful). There are critical unknowns in predicting success of trapand-haul programs, but minimizing stress experienced by fish throughout the process is clearly an important element affecting performance of fish subjected to trap-and-haul.

\section{Critical gaps in trap-and-haul knowledge}

The trap-and-haul case studies described above illustrate how oftentimes the programs evolve substantively over time. Technological advances, regulatory changes, improved biological understanding, and changing stakeholder priorities are common and these all precipitate new programmatic goals and objectives (Fig. 1). As part of our review, we identified several key information needs that are common across many trap-and-haul programs. The examples in this section can be used by fisheries managers to both assess how trap-and-haul processes can be improved at current facilities and to inform the planning and implementation of future programs.

Juveniles: post-transport survival

Few studies have evaluated post-transport survival of juvenile salmon and steelhead for the case study 
projects we reviewed. In general, evaluations on juvenile downstream migrants tend to focus on factors such as collection efficiency because effective collection of downstream migrants is a bottleneck for many programs (Lusardi and Moyle 2017; Kock et al. 2019a). These studies provide insights into the proportion of downstream migrants that are successfully collected and transported but typically provide little information on survival following release. Posttransport survival studies of downstream migrants would help managers understand how factors such as handling and transport methods contribute to delayed mortality of transported fish. There are several good research templates for evaluating post-transport survival questions, with many developed as part of the large-scale juvenile transportation program in the Columbia and Snake rivers (e.g., Muir et al. 2006; Rechisky et al. 2014; Gosselin and Anderson 2017). Examples include experimental post-transport holding evaluations and a variety of tagging studies to evaluate short- and long-term survival. While the Columbia and Snake river transportation program uses different transport methods (barges) with longer transport times $(>24 \mathrm{~h}$ ) and distances (up to $\sim 470 \mathrm{rkm}$ ) than the case study projects we described, their study designs could be readily adapted to assess post-transport survival of juvenile salmonids associated with other juvenile or adult trap-and-haul programs.

Juveniles: separation by species for transport

Research has shown that co-transport of juveniles from two or more fish species can result in increased stress levels and may have implications for postrelease survival (Congleton et al. 2000; Kelsey et al. 2002). For example, Congleton et al. (2000) found stress indices of juvenile Chinook salmon were highest during the peak of the outmigration period when transport loading densities were high, and salmon stress levels were correlated with steelhead loading density. Kelsey et al. (2002) reported cortisol levels were significantly higher for juvenile Chinook salmon held in tanks with juvenile steelhead than for salmon held without steelhead, and salmon behaviors differed among treatments. While these co-transport results suggest sorting collected fish by species and hauling them separately may be a good practice, it is possible additional handling offsets potential benefits of separation, particularly when transport times are short.
Downstream transport of juveniles in the two-way trap-and-haul programs described above currently occurs without segregation, although juveniles generally are separated from large-bodied fish including adult salmonids. Studies that compare post-release physiology and survival of groups of fish hauled with and without species separation and under various densities and water temperatures would be straightforward and would provide valuable information to inform whether segregation benefits outweigh additional handling stress.

Juveniles: head-of-reservoir collection

The development of effective head-of-reservoir juvenile collection systems is an important emerging research and development need. Such systems could facilitate two-way trap-and-haul programs at locations where reservoirs are large, have complex bathymetry, warm surface water temperatures, lack downstream velocity cues, or contain large populations of piscivorous predators. Juvenile salmon and steelhead mortality in these types of impoundments can be substantial (Rieman et al. 1991; NMFS 2008). The ability to collect a high proportion of downstream migrants at head-of-reservoir sites and transport them around the reservoir may improve the likelihood of program success at these locations. However, head-ofreservoir collection has rarely been attempted and successful systems have not been developed to date. Clancey et al. (2017) described a reservoir screen system that may eventually be used to modify water temperature near a potential head-of-reservoir fish collection system in Shasta Lake (California). The head-of-reservoir juvenile collection system in Shasta Lake would consist of an inclined plane collector with guidance nets and a temperature curtain located within approximately $1 \mathrm{~km}$ of where juveniles enter the reservoir from a tributary (BOR 2015). Currently, it is unclear whether downstream migrants can be successfully collected in reservoirs, and feasibility testing of prototype head-of-reservoir designs is needed.

Adults: prespawn mortality

As described previously, prespawn mortality of transported adults is a major management issue for some trap-and-haul programs. The mortality has been associated with a number of covariates, including fish 
traits (e.g., pathogen burden, injury status, energetic reserves, origin), handling and transport effects (e.g., collection and holding methods, transport density, transport distance), and river environment encountered before and after transport. Several research groups have addressed portions of the complex suite of factors that affect mortality in transported adult populations, but considerable uncertainty remains. It is likely the most influential factors will vary among species, trap-and-haul programs, locations, environmental conditions and years. Research that may help untangle the mechanisms affecting prespawn mortality include: studies addressing effects of specific trapand-haul protocols (e.g., Colvin et al. 2018) on adult stress and pathogen transmission; studies that evaluate alternatives to direct adult transport to spawning sites, such as temporary holding in facilities with high water quality (e.g., Benda et al. 2015) or release into thermally-stratified reservoirs where adults can select preferred thermal niches prior to spawning (e.g., Naughton et al. 2018); and studies that integrate behavior, experiences at collection facilities, and presumptive mortality risk factors.

Adults: post-transport reproductive success and cohort replacement

In an earlier section we discussed genetic studies by Baumsteiger et al. (2008), Sard et al. (2015, 2016), and Evans et al. (2016) that provided information on the reproductive success of transported adults. These studies showed that success varied substantially among individual adults and among years in trapand-haul populations in the Deschutes and Willamette river basins. Additional research on this topic would be valuable for several reasons. The use of genetics to track the reproductive success of individual fish can reveal important insights into factors such as adult transport timing, release location, and the effects of origin on the success of producing viable offspring. Such information can be useful for optimizing trapand-haul methods to maximize the number of juvenile fish produced by transported adults. Additionally, genetic or fish-marking studies may provide insights into factors such as how adults disperse from release locations and whether fish released in different locations or at different times have a reproductive advantage. In the South Fork McKenzie River, for example, fishery managers use separate release sites to spatially segregate groups of hatchery-origin and natural-origin fish.

One of the more promising genetic monitoring approaches is the use of parentage analysis to estimate adult-to-adult cohort replacement rates (Botsford and Brittnacher 1998; Sard et al. 2016). Cohort replacement can be estimated as the number of adults that return in future years (i.e., across all adult age classes) divided by the number of adults transported and released in a given brood year. Replacement greater than 1.0 would indicate that fish in the trap-and-haul program are self-sustaining or population growth is increasing. In contrast, a sequence of replacement estimates less than 1.0 would indicate population decline and potential sink dynamics. Comparing cohort replacement rates among transported and nontransported populations in a multi-year study would be useful for understanding whether trap-and-haul upstream of migration barriers significantly improves overall salmonid population dynamics.

\section{Populations: productivity}

A main goal of trap-and-haul programs is to expand population abundance and spatial distribution in a given basin by providing access for adult spawners to additional, and in many situations, more suitable habitat than if they were not provided upstream transport. Population expansion is most likely to occur if conditions such as water temperature and spawning habitat quality upstream from a dam can support biological outcomes (e.g., growth, survival) that result in a net increase in basin-wide productivity. Hypothetically, the combined juvenile productivity from adults that spawn upstream and downstream of a dam would be higher than productivity of the downstream group alone, unless transported adults that were culled from the downstream population are not contributing to overall reproductive success.

In addition to increased productivity and positive population growth rates, McElhany et al. (2000) identified three additional parameters that are key to evaluating and establishing the viability (i.e., having a negligible risk of extinction) of a salmonid population: overall population abundance, population spatial structure, and diversity. Trap-and-haul programs can influence population viability through each of these parameters. Generating productivity estimates for entire watersheds is expensive and logistically 
challenging. This is true even for a straightforward scenario such as with coho salmon, which have a noncomplex life cycle. The abundance of female spawners requires information on the number of smolts produced, marine survival and harvest exploitation rates, and the proportion of smolts that return as adult females (Bradford et al. 2000). Estimating smolt abundance requires either direct smolt assessments at migrant traps or information on the number of spawners, fecundity, egg deposition rates, and eggto-fry, fry-to-parr and parr-to-smolt survival (Ward and Slaney 1993). Not surprisingly, there have been few sustained efforts to calculate such estimates in existing trap-and-haul programs. However, collecting these data would allow potential impacts (e.g., Johnson et al. 2012) or benefits to population productivity from trap-and-haul to be evaluated, similar to evaluations of other conservation actions. For example, spatially explicit, multiple life-stage population models have been used to evaluate habitat variables (Honea et al. 2009) and climate effects on habitat restoration (Battin et al. 2007). Statistical analyses can assess changes in productivity (expressed as the per capita growth rate in the absence of harvest) associated with specific actions, such as hatchery production (Buhle et al. 2009). Quantifying spawner-recruit relationships, variability in productivity among species, watersheds and programs, and understanding potential limiting factors would help managers assess the effectiveness of trap-and-haul as a recovery or population expansion tool.

\section{Populations: life history diversity}

Simplifying the life-history portfolio of a population through anthropogenic activities has negative consequences on long-term population viability, and practices that help diversify population structure may be critical for populations subject to disturbance regimes (Greene et al. 2010) such as climate change (Battin et al. 2007). These activities can have major effects on phenotypic variation across a broad array of species and traits, and maintaining intraspecific phenotypic variation is an important component of conserving biodiversity (Thompson et al. 2019).

Trap-and-haul programs generally focus on collecting downstream migrants during the yearling smolt life stage, but this management approach may be insufficient for populations that express a mix of life history types. Chinook salmon in some impounded rivers, for example, move downstream as fry, subyearling smolts, yearling smolts, and age $1+$ smolts (Keefer et al. 2012; Schroeder et al. 2016). Collection efforts tend to target yearling smolts because these fish are larger, are physiologically prepared for seaward migration, and perhaps are more likely to seek downstream passage routes at dams. Active smolt outmigration for several species occurs in spring when reservoir surface temperatures are cool and surface collection is more likely to be feasible. In contrast, younger life stages tend to move downstream in a less directed fashion that includes rearing behavior (e.g., Connor et al. 2013; Bourret et al. 2016) and often occurs in summer when reservoir surface collection strategies are less effective. Thus, these fish are more challenging to collect, and the collection period often must occur over an extended period. Facilitating collection of all juvenile life history types should be prioritized at all sites as this is a key parameter of population viability (McElhany et al. 2000).

More generally, understanding existing-and ideally historical-life history diversity in a trap-andhaul population is a prerequisite to effectively preserving or restoring populations. Such traits are valued and needed for a population to persist and maintain long-term viability under future environmental conditions and intra- and inter-year variability. Conservation actions that address human impacts on phenotypic variation may be necessary to preserve evolutionarily significant biodiversity, such as the premature migrating phenotypes also known as "spring-run" (Thompson et al. 2019). Trap-and-haul is a potential conservation action to address the loss of phenotypic variation and life history diversity in target populations. However, when considering trap-andhaul as part of a reintroduction effort, the adaptive suitability of potential source stocks is needed, for example, due to the loss of spring-run alleles from selective pressures associated with dams (e.g., Thompson et al. 2019).

Populations: genetic, phenotypic, and demographic effects

The presence of migration barriers and the process of collecting and transporting fish around these barriers are likely to have a variety of population-level impacts (e.g., Angilletta et al. 2008; Thompson et al. 2019) that 
are currently not well understood. Migration delays at collection facilities can affect the phenology of upstream and downstream migrations and may also have important delayed effects on survival and fitness. For example, early migrating adult phenotypes that arrive late on spawning grounds may have reduced reproductive opportunity and decreased lifetime fitness (e.g., Dickerson et al. 2005). Similarly, ocean arrival timing for juveniles can be a critical determinant of growth opportunity and survival to adulthood Scheuerell et al. 2009; Satterthwaite et al. 2014; Weitkamp et al. 2015). Trap-and-haul operations should clearly strive to collect and transport fish at times when fish would be volitionally migrating, though this may initially be impractical in some systems. Managers and researchers should also attempt to understand the degree to which collection facilities select for specific phenotypes or demographic groups, as these types of selection biases can rapidly and significantly reduce the productivity and resilience of populations (e.g., Hard et al. 2008; Naish et al. 2008; Ohlberger et al. 2018).

\section{Populations: source/sink dynamics}

In some impounded rivers, adult salmonids successfully reproduce and may be self-sustaining downstream from dams. These fish may be natural-origin individuals using historical spawning sites in tributaries or main stem sites, or they may be the progeny of hatchery stocks or of hatchery-wild hybrids. In situations where origin is mixed or uncertain, it may be important for managers to limit the collection and transport of adult fish that originated downstream from the dam for trap-and-haul programs. This may be especially true when the downstream population has legal status (i.e., threatened or endangered, or species of concern) and low abundance. Trap-and-haul operations that capture natural-origin adults from downstream populations will likely result in lost production from the source populations (e.g., Schtickzelle and Quinn 2007; Johnson et al. 2012). Conversely, managers may seek to preserve a natural-origin population upstream from a dam by using selective trap-and-haul (e.g., Evans et al. 2016). In such cases, incidental collection of hatchery-origin or hybrid fish from below the dam may result in the transfer of undesirable genetic or phenotypic traits from the downstream population and reduce the productivity or fitness of the upstream population (e.g., Araki et al. 2008). To date, evaluations of source-sink dynamics have received little attention in trap-and-haul programs, despite the potential importance of these effects on programmatic and regional management and conservation goals.

Populations: effects on conspecifics and other endemic species

Adult source-sink dynamics are just one example of how trap-and-haul populations may affect conspecifics. The timing and location of post-transport juvenile releases may also affect juveniles that rear downstream via resource competition, especially for fish that may still be rearing (as opposed to activemigrant smolts). Juvenile salmonid release sites have also been associated with predator aggregations (Collis et al. 1995; Shively et al. 1996; Scheel and Hough 1997) that may increase mortality risk for both transported and resident fish. These effects, and perhaps others like pathogen transmission, can potentially occur at multiple spatial and temporal scales from site-specific effects within watersheds resulting in broader impacts on regional populations. Very few studies have examined potential effects of trap-andhaul on other native species (Hardiman et al. 2017; Upper Columbia United Tribes 2019), but such impacts should be considered. Transported salmonids may compete with or prey upon other species and have the potential to introduce pathogens or parasites. Trapand-haul effects on both conspecifics and other endemics may be of particular concern when large numbers of fish are transported relative to the abundance of natural-origin fish, and potential impacts should be carefully considered early in the decisionmaking process.

Operations: pathogen and parasite transmission

The potential for infected fish to infect other individuals during high-density holding and transport can be high (Ogut et al. 2005; Van Gaest et al. 2011), but pathogen infection prevalence and transmission rates have rarely been studied in trap-and-haul programs. For adults, horizontal transmission could have significant effects on the reproductive potential of transported fish if infectivity rates are high and result in prespawn mortality, as hypothesized by Benda et al. (2015) and Colvin et al. (2018). Juvenile migrants are 
also at risk of infection in collection facilities and during transport, while both juveniles and adults have the potential to infect non-transported conspecifics or congenerics after release. Research needs include: studies of pathogen and parasite prevalence in trapand-haul facilities and populations; identification of optimal fish transport densities to minimize infection rates; effectiveness tests of antibiotics or other prophylactic treatments on transported fish, where permitted (i.e., with hatchery-origin fish); and studies of the interactions among infectivity rates, collection facilities and transport tanks, environmental risk factors like warm water temperatures, and biological risk co-factors such as elevated stress and immunosuppression.

\section{Discussion}

Trap-and-haul: a tool for management and conservation

Trap-and-haul is one of the only options currently available to resource managers for reestablishing connectivity in impounded river systems. While dam removal is often proposed and discussed, it has rarely occurred in large rivers to date. Therefore, trap-andhaul is an important tool that provides access for nonlisted, threatened, and endangered salmon and steelhead to spawning and rearing habitats located upstream of impassable dams. Areas above dams often contain habitats that were occupied historically and are of high cultural importance, and reestablishing connectivity among river reaches can support fish population viability through increased abundance, productivity, diversity and spatial structure.

The 17 programs reviewed here were implemented to achieve a broad range of management objectives. In some cases, trap-and-haul is used simply to provide passage at a natural barrier (e.g., South Fork Skykomish River). At other locations, it has been used in attempts to reestablish self-sustaining populations of anadromous fish upstream of a dam (e.g., Deschutes and South Santiam rivers). Options for addressing fish passage at high-head dams are limited, and trap-andhaul can be used to address multiple management objectives. Furthermore, ESA-listed salmon and steelhead populations on the U.S. west coast have not recovered (Northwest Fisheries Science Center 2015), so it is not surprising that trap-and-haul use has expanded in the Pacific Northwest in recent decades. Implementation of trap-and-haul began as early as 1925, but more than half of the programs reviewed were implemented since 2000 (9 of 17 programs; Table 1). Older facilities have been modified if needed (e.g., Baker and Deschutes rivers) and the following programs are now being considered:

- On the upper Columbia River (Washington), the Upper Columbia United Tribes are moving forward with reintroduction efforts aimed at restoring salmon and steelhead to portions of the more than $1770 \mathrm{~km}$ of river and stream habitat blocked by Grand Coulee Dam (rkm 597; UCUT 2019).

- On the Yakima River (Washington), trap-and-haul will support efforts to provide passage upstream of six headwater dams, including Cle Elum Dam (BOR and DOE 2012), as described previously.

- In California, reintroduction may be necessary to achieve delisting criteria for ESA-listed salmonids in the Central Valley (NMFS 2014). Unoccupied habitats that historically supported winter-run Chinook salmon, spring-run Chinook salmon, or steelhead have been prioritized, including in the McCloud River, Battle Creek, the Yuba River, and the San Joaquin River (NMFS 2014); NMFS has been discussing the feasibility of reintroducing salmon and steelhead above high-head dams on the Yuba and Tuolumne rivers with stakeholders (personal communication, Steve Edmundson, National Oceanic and Atmospheric Administration).

- On the Chehalis River (Washington), local authorities have incorporated trap-and-haul into a proposed flood retention dam designed to operate intermittently for short periods (up to 32 days) when major and catastrophic floods are retained (https://chehalisbasinstrategy.com/eis/proposedproject/).

Critics of trap-and-haul point to costs associated with developing, installing, operating, and maintaining facilities and the potential for negative biological effects, such as those described above. These are valid concerns that also apply to volitional fish passage facilities. Given the limited options for providing fish passage at high-head dams, there remains an imminent need to advance the state-of-knowledge on trap-andhaul programs and their operations. Research on trap- 
and-haul continues and new studies are likely to provide additional insights that will improve our understanding of how this tool affects survival, adult spawning, reproductive success, juvenile life history diversity and overall population productivity. Data collected to date have primarily focused on quantifying the number of fish transported. At some sites trapping efficiency has also been evaluated. However, research techniques have advanced and can provide valuable information on individual- and populationlevel responses to trap-and-haul techniques. For example, in the South Santiam River, genetic studies have addressed productivity and population replacement questions (Evans et al. 2016; Weigel et al. 2019) and telemetry studies have evaluated post-release adult behaviors and survival (Keefer et al. 2010; Naughton et al. 2018). Similarly, genetic studies in the Cle Elum River have been used to identify stockspecific differences in spawning times, spawning location, and productivity (Matala et al. 2019), and telemetry has been used to estimate losses due to fallback and prespawn mortality (Kock et al. 2018b). These examples illustrate the type of detailed information that can be obtained and the importance of conducting a suite of studies to assess biological benefits and consequences of trap-and-haul and to collect data that can be used to optimize methods and protocols.

Context is critical when evaluating overall program effectiveness. Given this review, it seems appropriate that effectiveness be judged by stakeholders involved in each basin and program because they understand its management objectives, and their judgements should be informed by results of scientific studies and analyses. Lusardi and Moyle (2017) concluded that no two-way trap-and-haul program is an unequivocal success. However, given the diverse views by stakeholders of what constitutes program success and the different management objectives trap-and-haul programs are designed to meet, this conclusion is premature and unsubstantiated in our view, and does not align with evidence from many one-way trap-andhaul programs. Evaluating the success of a trap-andhaul program requires that multiple factors be considered. These include program-specific goals identified by stakeholders and resource managers, potential effects of parallel management actions in the basin, in-river conditions that fish face prior to collection and could face in the future, and population-level effects of hatchery supplementation, water management scenarios, ocean productivity, and climate. The characterization of a program as unsuccessful has little merit if neighboring populations that lack trap-and-haul are also in decline due to factors not related to trap and haul (i.e., poor ocean conditions, climate regime, hatchery effects). Conversely, characterizing a program as successful has little merit if cohort replacement is persistently less than 1.0 (e.g., Sard et al. 2015). Also, results from the evaluation of individual aspects of a trap-and-haul program should be viewed in the context of other passage options such as how volitional fishways perform. For example, up to $20 \%$ of the transported adults fall back at dams in some adult trap-and-haul programs (Kock et al. 2016, 2018b; Naughton et al. 2018), but this percentage is nearly identical to fallback documented at some run-of-river dams on the Snake and Columbia rivers where volitional passage occurs (Reischel and Bjornn 2003; Boggs et al. 2004; Naughton et al. 2006). Data to inform biological metrics such as cohort replacement rates need to be collected in basins with and without trap-and-transport to place overall trends in context, although this is challenging from a study design and cost standpoint. As noted above in the knowledge gaps section, information on multiple performance metrics is needed to fully evaluate and quantify the effects of trap-and-haul on fish populations. While identifying clearly defined metrics of success is an important first step in the development of a trap-and-haul program (Lusardi and Moyle 2017), assessing success is complex and its definition may substantively differ among stakeholders, river basins, and regions.

Tools are needed that address climate change

The development of trap-and-haul programs to reestablish salmonids upstream of impassable dams may be critical for population persistence if climate change predictions are realized in the coming decades (Mantua et al. 2010; Shanley and Albert 2014; Herbold et al. 2018; Crozier et al. 2019). Crozier et al. (2019) conducted a climate vulnerability assessment for salmon and steelhead populations in Washington, Oregon, and California and found that 23 of the 33 distinct population segments (DPS) evaluated had high or very high vulnerability ratings. Several of these DPSs were vulnerable to warm stream temperatures during both juvenile and adult freshwater life 
stages. In many rivers, volitional fish passage is available at main stem run-of-river and low-head diversion dams, but high-head storage dams block access to headwater, tributary streams that can contain extensive suitable spawning and rearing habitat. These areas are likely to be more resistant to climate change compared to areas located lower in watersheds. Highelevation tributaries can serve as climate refuges, support increased diversity, and provide for larger populations if fish are provided access (Crozier et al. 2019). In California, improving access to upstream habitats is likely to improve the ability of salmon to persist in a changing climate (Herbold et al. 2018). While access to these areas is blocked in many basins, interest in developing reintroduction programs to restore salmonid populations upstream of impassable dams is ongoing. Short of dam removal, trap-and-haul is one of few, and may be the only economical and culturally acceptable option at these dams to restore watershed connectivity and expand population productivity.

Developing new technologies and refining best management practices are critical steps needed to support trap-and-haul efforts in the future and help address effects of climate change. Fish collection is often a bottleneck (Lusardi and Moyle 2017) that can result in migration delay, increase stress levels in fish, and in extreme cases prevent passage for a significant portion of a juvenile or adult population. Technological advances aimed at increasing attraction, entrance, and retention characteristics at existing fish traps and collection facilities will significantly improve the process of trapping and transporting fish. Also, development of new collection systems capable of collecting fish at novel locations, such as head-ofreservoir sites, may significantly improve the ability to maximize fish collection rates, reduce losses that occur during migration through the reservoir, and support maintenance of life history diversity and overall productivity of salmon and steelhead populations. Optimized fish holding and handling procedures are likely to be important in the future to minimize stress and its associated effects on the physiologic and performance characteristics of transported fish, because transported individuals are likely to face increasingly challenging conditions in other portions of their migratory pathways (Herbold et al. 2018; Crozier et al. 2019). Periodic reviews to summarize the state-of-knowledge on trap-and-haul programs, such as this one, are needed to inform resource management and conservation actions.

Integrated, adaptive, and sustained management

Trap-and-haul is often implemented as one of several management actions in a watershed that includes - for example-habitat restoration, streamflow regulation, water diversion screening, and hatchery supplementation. To optimize success, these activities should be implemented as an integrated suite of actions. Recent studies have identified trap-and-haul as an important element in the management toolbox (Lusardi and Moyle 2017; Herbold et al. 2018; Crozier et al. 2019) and there are specific aspects of the river environment that can sometimes be managed to enhance these activities. For example, while high-head dams restrict passage to upstream areas, they also store cold water deep in their reservoirs. At some locations, such as Cougar and Detroit dams in the Willamette River Basin, this cold water is used to manage water temperatures in downstream river reaches to support resident and anadromous salmonid spawning and rearing. In 2004, Cougar Dam was retrofitted with a water temperature control tower that allows water to be released from varying depths in the forebay. A similar project is under development at Detroit Dam in conjunction with a new juvenile fish collection facility. The integrated fish transport and river temperature management facilities should help address multiple fishery objectives upstream and downstream of dams in both river systems.

These Willamette River Basin examples point to a growing trend where salmonid productivity and anadromy is supported throughout a watershed by a broad suite of management actions. This includes managing environmental conditions downstream of dams, re-establishing connectivity to headwater habitats upstream of dams through adult trap-and-haul and supporting life history diversity and life-cycle productivity by collecting juveniles across the entire calendar year and transporting them downstream. This expanded capability to manage a broad spectrum of the river will be useful to resource managers. For example, downstream water temperatures and flow could be managed to increase the effectiveness of habitat restoration, improve conditions for adult salmon and steelhead migrating upstream to reach a collection facility, reduce stress while holding prior to 
collection, minimize stress during collection, holding and transport, and reduce prespawn mortality after release.

Implementation needs to be adaptively managed and supported long-term

Trap-and-haul requires a long-term commitment of time and resources and the resulting studies and operations being implemented must be adaptively managed and supported to ensure they are effective (Fig. 1). This is because design criteria have been developed to maximize the likelihood of collection success and ensure fish safety at juvenile and adult collection facilities, but variability in performance occurs due to localized environmental conditions, project operations, the configuration of the reservoir relative to the dam, and by fish species and life stage. Performance can also vary within a given year and among years as environmental conditions and water levels in a reservoir change, and with basin hydrology and climate.

Each trap-and-haul system is unique, and within a given system day-to-day variation in the level of stress experienced occurs (Schreck et al. 2006). The severity of stress experienced is a function of numerous variables including: (1) the general wellbeing of the fish as they enter a trapping system (e.g., are they already stressed or infected); (2) how close the other environmental variables being experienced by the fish are to being optimal for the species involved (e.g., water that is above optimal can have an exponentiallyincreasing negative effect as it approaches tolerance levels); (3) the duration of each stressful element of trap-and-haul that is experienced (in general, the longer the exposure to a stressor, the exponentially greater the stress experienced); and (4) the cumulative effects of stressors of each element of trap-and-haul (e.g., traps can be injurious to fish, and the loading of a transportation vehicle, and the release system and process can each be very stressful). There are critical unknowns in predicting the success of trap-and-haul programs, but minimizing stress experienced by fish throughout the process is clearly an important element affecting the performance of fish subjected to trapand-haul.

The considerable variation in effectiveness among systems discussed above underscores the importance of conducting robust evaluations during the pre-design phase of a trap-and-haul program. The efficacy of the program relies on collection of information about where juvenile and adult fish congregate near potential collection locations under different operational scenarios, how juvenile fish distribute in the water column of a reservoir seasonally, and during which times of the year fish are expected to be near the collection location and available for capture. Similarly, the physical nature of the collection system needs to be evaluated carefully to optimize the design of the various system elements and ascertain not only how well the system will collect fish but also the effect of the collection on fish wellbeing. All elements including discovery, entry, passage to holding facilities, separation and handling, transport vehicle loading, inroute specifics, vehicle release system, release timing, and release location need to be considered.

This review highlights the importance of starting with design guidelines and then assessing the sitespecific criteria required for a successful passage program through rigorous observation of local conditions. Implementation of trap-and-haul programs requires years, if not decades, to design, install, and test facility performance, discuss test results with stakeholders, and make decisions on adaptive changes to facilities or operations. The changes will then require additional design and testing. In short, the development of a successful trap-and-haul program requires a commitment by stakeholders, regulators, and project owners to a long-term process of continued evaluation that ideally follows an adaptive management strategy developed and agreed upon before implementation, and a financial commitment to the approach.

\section{Summary}

The goal of this review was to provide a comprehensive synthesis of the current state-of-knowledge on trap-and-haul for management of Pacific salmonid populations in impounded river systems. Numerous trap-and-haul programs exist throughout the Pacific Northwest, with operating histories ranging from years to decades and with a broad range of management goals and objectives. The development and operation of trap-and-haul infrastructure is guided by established criteria and a solid research base on many aspects of fish behavior. However, fish handling, an 
intrinsic requirement of trap-and-haul, can increase fish stress which is negatively associated with fish health and survival. Thus, improvements to infrastructure and fish handling protocols should strive to minimize stress effects.

Existing programs have experienced a range of successes, but all remain in operation to date. Apparent successes are based on increased numbers of fish transported (e.g., Baker River and White River) or populations being judged as self-sustaining (Fall Creek), while failures are based on population replacement rates being less than 1.0 (South Fork McKenzie River). There have also been programs that have experienced operational challenges (Toutle River). It can take years of adaptive management to achieve trap-and-haul performance objectives, and because of this, judging success based on one study or a short period may lead to premature conclusions. Several aspects of the trap-and-haul process have been evaluated but critical information gaps remain, and additional information is required to fully understand how trap-and-haul affects Pacific salmonids in impounded river systems. In large rivers with dams, the continued development of trap-and-haul is likely to be critical for resource managers attempting to maintain and recover Pacific salmon populations, their viability, and their resilience to environmental variability, including climate change.

Acknowledgements Funding for this study was provided by the National Oceanic and Atmospheric Administration (NOAA), National Marine Fisheries Service (NMFS), Office of Habitat Conservation. Data and insights were provided by Brett Boyd, Greg Grenbemer, Kurt Kremers, and Dan Peck (Oregon Department of Fish and Wildlife), Ed Eleazer and John Serl (Washington Department of Fish and Wildlife), Dan Baker and Eric Johnson (Idaho Fish and Game), Fred Goetz, Greg Taylor and Doug Garletts (U.S. Army Corps of Engineers), Bill Bosch (Yakama Nation Fisheries), Nick Verretto (Puget Sound Energy), and Steve Edmundson (NOAA Fisheries). We thank Dave Beauchamp, Nick Verretto, and one anonymous reviewer for helpful comments on this manuscript.

Open Access This article is licensed under a Creative Commons Attribution 4.0 International License, which permits use, sharing, adaptation, distribution and reproduction in any medium or format, as long as you give appropriate credit to the original author(s) and the source, provide a link to the Creative Commons licence, and indicate if changes were made. The images or other third party material in this article are included in the article's Creative Commons licence, unless indicated otherwise in a credit line to the material. If material is not included in the article's Creative Commons licence and your intended use is not permitted by statutory regulation or exceeds the permitted use, you will need to obtain permission directly from the copyright holder. To view a copy of this licence, visit http://creativecommons.org/licenses/by/4.0/.

\section{References}

Achord S, Zabel RW, Sandford BP (2007) Migration timing, growth, and estimated parr-to-smolt survival rates of wild Snake River spring-summer Chinook salmon from the Salmon River Basin, Idaho, to the lower Snake River. Trans Am Fish Soc 136:142-154. https://doi.org/10.1577/ T05-308.1

Adams NS, Johnson GE, Rondorf DW, Anglea SM, Wik T (2001) Biological evaluation of the behavioral guidance structure at Lower Granite Dam on the Snake River, Washington in 1998. Am Fish Soc Symp 26:145-160

Adams NS, Plumb JM, Perry RW, Rondorf DW (2014) Performance of a surface bypass structure to enhance juvenile steelhead passage and survival at Lower Granite Dam, Washington. N Am J Fish Manag 34:576-594. https://doi. org/10.1080/02755947.2014.901256

Al-Chokhachy R, Clark CL, Sorel MH, Beauchamp DA (2018) Development of new information to inform fish passage decisions at the Yale and Merwin hydro projects on the Lewis River, Washington. U.S. Geological Survey OpenFile Report 2018-1190. https://doi.org/10.3133/ofr20 181190

Angilletta MJ, Steel EA, Bartz KK, Kingsolver JG, Scheuerell MD, Beckman BR, Crozier LG (2008) Big dams and salmon evolution: changes in thermal regimes and their potential evolutionary consequences. Evol Appl 1:286299. https://doi.org/10.1111/j.1752-4571.2008.00032.x

Araki H, Berejikian BA, Ford MJ, Blouin MS (2008) Fitness of hatchery-reared salmonids in the wild. Evol Appl 1:3 42-355. https://doi.org/10.1111/j.1752-4571.2008.00026. $\mathrm{x}$

Arriaza JL, Boughton DA, Urquhart K, Mangel M (2017) Sizeconditional smolting and the response of Carmel River steelhead to two decades of conservation efforts. PLoS ONE 12(11):e0188971

Baker DJ, Demien W (2017) Snake River sockeye salmon captive broodstock program hatchery element, 2016. Annual report to the Bonneville Power Administration, Project 200740200, Portland, Oregon. https:// collaboration.idfg.idaho.gov/FisheriesTechnicalReports/ Res17-08Baker2016Snake\%20River\%20Sockeye\%20 Salmon\%20Captive\%20Broodstock\%20Program\% 20Hatchery\%20Element.pdf. Accessed 2 Apr 2020

Battin J, Wiley MW, Ruckelshaus MH, Palmer RN, Korb E, Bartz KK, Imaki H (2007) Projected impacts of future climate change on salmon habitat restoration. Proc Natl Acad Sci 104:6720-6725. https://doi.org/10.1073/pnas. 0701685104

Baumsteiger J, Hand DM, Olson DE, Spateholts R, Fitzgerald G, Arden WR (2008) Use of parentage analysis to determine reproductive success of hatchery-origin spring Chinook salmon outplanted into Shitike Creek, Oregon. N Am 
J Fish Manag 28:1472-1485. https://doi.org/10.1577/M07195.1

Beeman JW, Adams NS (2015) In-reservoir behavior, dam passage, and downstream migration of juvenile Chinook salmon and juvenile steelhead from Detroit Reservoir and Dam to Portland, Oregon, February 2013-February 2014. U.S. Geological Survey Open File Report 2015-1090. https://doi.org/10.3133/ofr20151090

Beeman JW, Evans SD, Haner PV, Hansel HC, Hansen AC, Hansen GS, Hatton TW, Sprando JM, Smith CD, Adams NS (2016a) Evaluation of the biological and hydraulic performance of the portable floating fish collector at Cougar Reservoir and Dam, Oregon, 2014: U.S. Geological Survey Open-File Report 2016-1003. https://doi.org/10. 3133/ofr20161003

Beeman JB, Evans SD, Haner PV, Hansel HC, Hansen AC, Hansen GS, Hatton TW, Kofoot EE, Sprando JM (2016b) Evaluation of the biological and hydraulic performance of the portable floating fish collector at Cougar Reservoir and Dam, Oregon, September 2015-January 2016: U.S. Geological Survey Open File Report 2016-1197. https://doi. org/10.3133/ofr20161197

Benda SE, Naughton GP, Caudill DD, Kent ML, Schreck CB (2015) Cool, pathogen-free refuge lowers pathogen-associated prespawn mortality of Willamette River Chinook salmon. Trans Am Fish Soc 144:1159-1172. https://doi. org/10.1080/00028487.2015.1073621

Bickford SA, Skalski JR (2000) Reanalysis and interpretation of 25 years of Snake-Columbia River juvenile salmonid survival studies. N Am J Fish Manag 20:53-68. https://doi. org/10.1577/1548-8675(2000)020\%3c0053:RAIOYO\% 3e2.0.CO;2

Boggs CT, Keefer ML, Peery CA, Bjornn TC, Stuehrenberg LC (2004) Fallback, reascension, and adjusted fishway escapement estimates for adult Chinook salmon and steelhead at Columbia and Snake river dams. Trans Am Fish Soc 133:932-949. https://doi.org/10.1577/T03-133.1

Botsford LW, Brittnacher JG (1998) Viability of Sacramento River winter-run Chinook salmon. Conserv Biol 12:65-79. https://doi.org/10.1111/j.1523-1739.1998.96180.x

Bourret SL, Caudill CC, Keefer ML (2016) Diversity of juvenile Chinook salmon life history pathways. Riv Fish Biol Fish 26:375-403. https://doi.org/10.1007/s11160-016-9432-3

Bowerman T, Keefer ML, Caudill CC (2016) Pacific salmon prespawn mortality: patterns, methods, and study design consideration. Fisheries 12:738-749. https://doi.org/10. 1080/03632415.2016.1245993

Bowerman T, Roumasset A, Keefer ML, Sharpe CS, Caudill CC (2018) Prespawn mortality of female Chinook salmon increases with water temperature and percent hatchery origin. Trans Am Fish Soc 147:31-42. https://doi.org/10. 1002/tafs. 10022

Bradford MJ, Myers RA, Irvine JR (2000) Reference points for coho salmon (Oncorhynchus kisutch) harvest rates and escapement goals based on freshwater production. Can J Fish Aquat Sci 57:677-686. https://doi.org/10.1139/f99281

Brandt JR, Monzyk FR, Romer JD, Emig R (2016) Status and trends of predator species in Lookout Point Reservoir. Report by the Oregon Department of Fish and Wildlife to the U.S. Army Corps of Engineers, Portland, Oregon. https://odfw.forestry.oregonstate.edu/willamettesalmonidrme/ sites/default/files/reservoir-research/status_and_trends_of_ predator_species_in_lookout_point_reservoir-with_npm_ rt_-final.pdf. Accessed 2 Apr 2020

Bromaghin JF, Underwood TJ, Hander RF (2007) Residual effects from fish wheel capture and handling of Yukon River fall chum salmon. N Am J Fish Manag 27:860-872. https://doi.org/10.1577/M05-204.1

Buhle ER, Holsman K, Scheuerell M, Albaugh A (2009) Using an unplanned experiment to evaluate the effects of hatcheries and environmental variation on threatened populations of wild salmon. Biol Conserv. https://doi.org/10. 1016/j.biocon.2009.05.013

Bunt CM, Castro-Santos T, Haro A (2012) Performance of fish passage structures at upstream barriers to migration. River Res Appl 28:457-478. https://doi.org/10.1002/rra.1565

Bureau of Reclamation (2007) Assessment of sockeye salmon production potential in the Cle Elum River Basin, storage dam fish passage study, Yakima Project, Washington, Technical Series No. PN-YDFP-008, Boise, Idaho. https:// www.usbr.gov/pn/studies/fishpassage/activities/CleElumSockeye.pdf. Accessed 2 Apr 2020

Bureau of Reclamation (2011) Final planning report-Cle Elum Dam fish passage facilities. Bureau of Reclamation technical report. https://www.usbr.gov/pn/programs/eis/cleelum/final-plan-rpt.pdf. Accessed 2 Apr 2020

Bureau of Reclamation (2015) Shasta Dam fish passage evaluation draft pilot implementation plan. Department of Interior, Bureau of Reclamation. Mid-Pacific Region. https://www.usbr.gov/mp/bdo/docs/shasta-pilot-imp-plan. pdf. Accessed 2 Apr 2020

Bureau of Reclamation (2016) Helix design for downstream fish passage at Cle Elum Dam. Final Report by the Bureau of Reclamation, report number HK-2012-01, Denver, Colorado. https://www.usbr.gov/tsc/techreferences/hydraulics_ lab/pubs/HL/HL-2015-01.pdf. Accessed 2 Apr 2020

BOR and DOE (Bureau of Reclamation and Washington State Department of Ecology) (2012) Yakima River Basin integrated water resource management plan-final programmatic environmental impact statement. Prepared by ESA and HDR Engineering, Inc., for Bureau of Reclamation. https://www.usbr.gov/pn/programs/yrbwep/reports/ FPEIS/fpeis.pdf. Accessed 2 Apr 2020

Cada GF (2001) The development of advanced hydroelectric turbines to improve fish passage survival. Fisheries 26(9):14-23. https://doi.org/10.1577/1548-8446(2001)0 26\%3c0014:TDOAHT\%3e2.0.CO;2

Caudill CC, Daigle WR, Keefer ML, Boggs CT, Jepson MA, Burke BJ, Zabel RW, Bjornn TC, Peery CA (2007) Slow dam passage in adult Columbia River salmonids associated with unsuccessful migration: delayed negative effects of passage obstacles or condition-dependent mortality. Can J Fish Aquat Sci 64:979-995. https://doi.org/10.1139/f07065

Caudill CC, Keefer ML, Clabough TS, Naughton GP, Burke BJ, Peery CA (2013) Indirect effects of impoundment on migrating fish: temperature gradients in fish ladders slow dam passage by adult Chinook salmon and steelhead. PLoS ONE 8(12):e85586

Clancey K, Saito L, Hellmann K, Svoboda C, Hannon J, Beckwith R (2017) Evaluating head-of-reservoir water 
temperature for juvenile Chinook salmon and steelhead at Shasta Lake with modeled temperature curtains. N Am J Fish Manag 37:1161-1175. https://doi.org/10.1080/ 02755947.2017.1350223

Clarkson RW, Childs MR (2000) Temperature effects of hypolimnial-release dams on early life stages of Colorado River big-river fishes. Copeia 2:402-412. https://doi.org/ 10.1643/0045-8511(2000)000[0402:TEOHRD]2.0.CO;2

Clay CH (1995) Design of fishways and other fish facilities, 2nd edn. CRC Press, Boca Raton

Cogliati KM, Heron CL, Noakes DLG, Schreck CP (2019) Reduced stress response in juvenile Chinook salmon reared with structure. Aquaculture 504:96-101

Collins GB, Elling CH (1964) Summary of progress in fish passage research. U.S Bureau of Commercial Fisheries, Northwest Alaska Fisheries Center, Seattle

Collis K, Beaty RE, Crain BR (1995) Changes in catch rate and diet of northern squawfish associated with the release of hatchery-reared juvenile salmonids in a Columbia River reservoir. N Am J Fish Manag 15(2):346-357. https://doi. org/10.1577/1548-8675(1995)015\%3c0346:CICRAD\% 3e2.3.CO;2

Colvin ME, Peterson JT, Kent ML, Schreck CB (2015) Occupancy modeling for improved accuracy and understanding of pathogen prevalence and dynamics. PLoS ONE. https:// doi.org/10.1371/joural.pone.0116605

Colvin ME, Peterson JT, Sharpe C, Kent ML, Schreck CB (2018) Identifying optimal hauling densities for adult Chinook salmon trap-and-haul operations. River Res Appl 34:1158-1167. https://doi.org/10.1002/rra.3348

Congleton JL, LaVoie WJ, Schreck CB, Davis LE (2000) Stress indices in migrating juvenile salmon and steelhead of wild and hatchery origin before and after barge transportation. Trans Am Fish Soc 129:946-961. https://doi.org/10.1577/ 1548-8659(2000)129\%3c0946:SIIMJC\%3e2.3.CO;2

Connor WP, Tiffan KF, Plumb JM, Moffitt CM (2013) Evidence for density-dependent changes in growth, downstream movement, and size of Chinook Salmon subyearlings in a large-river landscape. Trans Am Fish Soc 142:1453-1468. https://doi.org/10.1080/00028487.2013.806953

Coutant CC, Whitney RR (2000) Fish behavior in relation to passage through hydropower turbines: a review. Trans Am Fish Soc 129:351-380. https://doi.org/10.1577/15488659(2000)129\%3c0351:FBIRTP\%3e2.0.CO;2

Crozier LG, McClure MM, Beechie T, Bograd SJ, Boughton DA, Carr M, Cooney TD, Dunham JB, Greene CM, Haltuch MA, Hazen EL, Holzer DM, Huff DD, Johnson RC, Jordan CE, Kaplan ID, Lindley ST, Mantua NJ, Moyle PB, Myers JM, Nelson MW, Spence BC, Weitkamp LA, Williams TH, Willis-Norton E (2019) Climate vulnerability assessment for Pacific salmon and steelhead in the California current large marine ecosystem. PLoS ONE 14(7):e0217711. https://doi.org/10.1371/journal.pone. 0217711

DeWeber JT, Peterson JT, Sharpe C, Kent ML, Colvin ME, Schreck CB (2017) A hidden-process model for estimating prespawn mortality using carcass survey data. N Am J Fish Manag 37:162-175. https://doi.org/10.1080/02755947. 2016.1245223

Dickerson BR, Brinck KW, Willson MF, Bentzen P, Quinn TP (2005) Relative importance of salmon body size and arrival time at breeding grounds to reproductive success. Ecology 86(2):347-352. https://doi.org/10.1890/03-625

Evans AF, Wertheimer RH, Keefer ML, Boggs CT, Peery CA, Collis K (2008) Transportation of steelhead kelts to increase interoparity in the Columbia and Snake rivers. N Am J Fish Manag 28:1818-1827. https://doi.org/10. 1577/M08-043.1

Evans ML, Shry SJ, Jacobsen DB, Sard NM, O'Malley KG (2015) Functional gene diversity and migration timing in reintroduced Chinook salmon. Conserv Genet 16:1455-1464. https://doi.org/10.1007/s10592-015-0753$\mathrm{x}$

Evans ML, Johnson MA, Jacobson D, Wang J, Hogansen M, O’Malley KG (2016) Evaluating a multi-generational reintroduction program for threatened salmon using genetic parentage analysis. Can J Fish Aquat Sci 73:1-9. https://doi.org/10.1139/cjfas-2015-0317

Fast D, Johnston M, Bosch B, Bryan J (2016) Whooshh transport survival efficacy is reproducible across a three-year viability assessment study. Report by Yakama Nation Fisheries and Whooshh Innovations, Seattle, Washington. https://www.whooshh.com/Roza\%20Yr\%203\% 20Viability\%20Study04.18.17\%20final.pdf. Accessed 6 Apr 2020

Ferguson JW, Sandford BP, Reagan RR, Gilbreath LG, Meyer EB, Ledgerwood RD, Adams NS (2007) Bypass modification at Bonneville Dam on the Columbia River improved survival of juvenile salmon. Trans Am Fish Soc 136:1487-1510. https://doi.org/10.1577/T06-158.1

Ferguson JW, Healey M, Dugan P, Barlow C (2011) Potential effects of dams on migratory fish in the Mekong River: lessons from salmon in the Fraser and Columbia rivers. 2011. Environ Manag 47:141-159. https://doi.org/10. 1007/s00267-010-9563-6

Feist BE, Anderson JJ (1991) Review of fish behavior relevant to fish guidance systems: annual report of research. University of Washington, Fisheries Research Unit, Report FRI-UW-9102. Seattle, Washington. https://doi.org/10. 13140/2.1.1172.8161

Fish Commission of the State of Oregon (1960) Evaluation of the ability of an artificial outlet to attract downstream migrant salmonids from the reservoir of Lookout Point Dam. Report to the U.S. Army Corps of Engineers. Fish Commission of the State of Oregon, Portland. https:// books.google.com/books?id=QHdQAAAAYAAJ\&lpg= PP65\&ots=9PozCKYsXs\&dq=Evaluation $\% 20$ of $\% 20$ the $\%$ 20ability\%20of\%20an\%20artificial\%20outlet $\% 20$ to $\% 20$ attract $\% 20$ downstream $\% 20$ migrant $\% 20$ salmonids $\% 20$ from $\% 20$ the $\% 20$ reservoir\%20 of\%20Lookout\%20Point $\% 20 \mathrm{Dam} . \& \mathrm{pg}=\mathrm{PP} 11 \mathrm{\# v}=$ onepage $\& \mathrm{q}=$ Evaluation $\% 20$ of $\% 20$ the $\% 20$ ability $\% 20$ of $\% 20$ an $\% 20$ artificial $\% 20$ outlet $\%$ 20 to $\% 20$ attract $\% 20$ downstream $\% 20$ migrant $\% 20$ salmonids $\% 20$ from $\% 20$ the $\% 20$ reservoir\%20of\%20Lookout $\% 20$ Point \%20Dam.\&f=false. Accessed 7 Apr 2020

Fjelstad HP, Pulg U, Forseth T (2018) Safe two-way migration for salmonids and eel past hydropower structures in Europe: a review and recommendation for best-practice solutions. Mar Freshw Res 69:1834-1847. https://doi.org/10. 1071/MF18120

Frank HJ, Mather ME (2009) What is "fallback"? Metrics needed to assess telemetry tag effects on anadromous fish 
behavior. Hydrobiologia 635:237-249. https://doi.org/10. 1007/s10750-009-9917-3

Frechette DM, Goerig E, Bergeron NE (2019) Factors influencing fallback by adult Atlantic salmon following transport in a novel river reach. Fish Manag Ecol 27:20-31. https://doi.org/10.1111/fme.12378

Fukushima M, Kameyama S, Kaneko M, Nakao K, Steel EA (2007) Modelling the effects of dams on freshwater fish distributions in Hokkaido, Japan. Freshw Biol 52:1511-1524. https://doi.org/10.1111/j.1365-2427.2007. 01783.x

Geist DR, Colotelo AH, Linley TJ, Wagner KA, Miracle AL (2016) Effects of a novel fish transport system on the health of adult fall Chinook salmon. J Fish Wildl Manag 7:347-358. https://doi.org/10.3996/102015-JFWM-108

Glicken H (1998) Rockslide-debris avalanche of May 18, 1980, Mount St. Helens volcano, Washington: Bulletin of the Geological Survey of Japan, vol 49, pp 55-106. https:// www.gsj.jp/data/bull-gsj/49-0203_01.pdf. Accessed 7 Apr 2020

Gosselin JL, Anderson JJ (2017) Combining migration history, river conditions, and fish condition to examine cross-lifestage effects on marine survival in Chinook salmon. Trans Am Fish Soc 146:408-421. https://doi.org/10.1080/ 00028487.2017 .1281166

Greene CM, Hall JE, Guilbalt KR, Quinn TP (2010) Improved viability of populations with diverse life-history portfolios. Biol Lett 6:382-386. https://doi.org/10.1098/rsbl.2009. 0780

Hagelin A, Calles O, Greenberg L, Piccolo J, Bergman E (2016) Spawning migration of wild and supplementary stocked landlocked Atlantic salmon (Salmo salar). River Res Appl 32:383-389. https://doi.org/10.1002/rra.2870

Hansen MJ, Steel AE, Cocherell DE, Patrick PH, Sills M, Cooke SJ, Carr KJ, Kavvas ML, Fangue NA (2019) Experimental evaluation of the effect of a light-emitting diode device on Chinook salmon smolt entrainment in a simulated river. Hydrobiologia. https://doi.org/10.1007/s10750-019-0402 2-1.10.1007/s10750-019-04022-1

Hard JJ, Gross MR, Heino M, Hilborn R, Kope RG, Law R, Reynolds JD (2008) Evolutionary consequences of fishing and their implications for salmon. Evol Appl 1(2):388-408. https://doi.org/10.1111/j.1752-4571.2008.00020.x

Hardiman JM, Breyta RB, Haskell CA, Ostberg CO, Hatten JR, Connolly PJ (2017) Risk assessment for the reintroduction of anadromous salmonids upstream of Chief Joseph and Grand Coulee Dams, northeastern Washington: U.S. Geological Survey Open-File Report 2017-1113. https:// doi.org/10.3133/ofr20171113

Harmon JR (2003) A trap for handling adult anadromous salmonids at Lower Granite Dam on the Snake River, Washington. N Am J Fish Manag 23:989-992. https://doi. org/10.1577/M02-035

Harmon TS (2009) Methods for reducing stressors and maintaining water quality associated with live fish transport in tanks: a review of the basics. Rev Aquac 1:58-66. https:// doi.org/10.1111/j.1753-5131.2008.01003.x

Haro A, Odeh M, Noreika J, Castro-Santos T (1998) Effect of water acceleration on downstream migratory behavior and passage of Atlantic salmon smolts and juvenile American shad at surface bypasses. Trans Am Fish Soc 127:118-127. https://doi.org/10.1577/1548-8659(1998)127\%3c0118: EOWAOD\%3e2.0.CO; 2

Haro A, Castro-Santos T, Noreika J, Odeh M (2004) Swimming performance of upstream migrant fishes in open-channel flow: a new approach to predicting passage through velocity barriers. Can J Fish Aquat Sci 61:1590-1601. https://doi.org/10.1139/f04-093

Herbold B, Carlson SM, Henery R, Johnson RC, Mantua N, McClure M, Moyle P, Sommer T (2018) Managing for salmon resilience in California's variable and changing climate. San Francisco Estuary and Watershed Science 16 article 3. https://doi.org/10.15447/sfews.2018v16iss2art3

Hillgruber N, Zimmerman CE (2009) Estuarine ecology of juvenile salmon in western Alaska: a review. Am Fish Soc Symp 70:183-199

Hinch SG, Cooke SJ, Farrell AP, Miller KM, LaPointe M, Patterson DA (2012) Dead fish swimming: a review of research on the early migration and high premature mortality in adult Fraser River sockeye salmon Oncorhynchus nerka. J Fish Biol 81:576-599. https://doi.org/10.1111/j. 1095-8649.2012.03360.x

Honea J, Jorgensen J, McClure M, Cooney T, Engie K, Hilborn R (2009) Evaluating habitat effects on population status: Influence of habitat restoration on spring-run Chinook salmon. Freshw Biol 54:1576-1592. https://doi.org/10. 1111/j.1365-2427.2009.02208.x

Hughes JS, Kim J, Vazquez JA, Johnson GE (2014) Hydroacoustic evaluation of juvenile salmonid passage and distribution at Foster Dam, 2013-2014. PNNL-23645. Final report submitted by the Pacific Northwest National Laboratory to the U.S. Army Corps of Engineers, Portland, Oregon.

Hughes JS, Bellgraph BJ, Kim J, Vernon CV, Fisher EF, Green ED, Liss SA, Deters KA, Johnson GE (2016) Evaluation of juvenile salmonid passage and behavior at Foster Dam using radio telemetry, 2015. PNNL-25253. Final report submitted by the Pacific Northwest National Laboratory to the U. S. Army Corps of Engineers, Portland, Oregon.

Johnson GE, Dauble DD (2006) Surface flow outlets to protect juvenile salmonids passing through hydropower dams. Rev Fish Sci 143(3):213-244. https://doi.org/10.1080/ 10641260600864023

Johnson GE, Anglea SM, Adams NS, Wik TO (2005) Evaluation of a prototype surface flow bypass for juvenile salmon and steelhead to the powerhouse of Lower Granite Dam, Snake River, Washington, 1996-2000. N Am J Fish Manag 25:138-151. https://doi.org/10.1577/M04-024.1

Johnson RC, Weber PK, Wikert JD, Workman ML, MacFarlane RB, Grove MJ, Schmitt AK (2012) Managed metapopulations: do salmon hatchery "sources" lead to in-river "sinks" in conservation? PLoS ONE 7(2):e28880. https:// doi.org/10.1371/journal.pone.0028880

Katopodis C, Williams JG (2012) The development of fish passage research in a historical context. Ecol Eng 48:8-18. https://doi.org/10.1016/j.ecoleng.2011.07.004

Kareiva P, Marvier M, McClure M (2000) Recovery and management options for spring/summer Chinook salmon in the Columbia River basin. Science 290:977-979. https://doi. org/10.1126/science.290.5493.977

Keefer ML, Caudill CC (2014) Homing and straying by anadromous salmonids: a review of mechanisms and rates. 
Rev Fish Biol Fish 24:333-368. https://doi.org/10.1007/ s11160-013-9334-6

Keefer ML, Peery CA, Ringe RR, Bjornn TC (2004) Regurgitation rates of intragastric radio transmitter by adult Chinook salmon and steelhead during upstream migration in the Columbia and Snake rivers. N Am J Fish Manag 24:47-54. https://doi.org/10.1577/M02-128

Keefer ML, Peery CA, Daigle WR, Jepson MA, Lee SR, Boggs CT, Tolotti KR, Burke BJ (2005) Escapement, harvest and unknown loss of radio-tagged adult salmonids in the Columbia River-Snake River hydrosystem. Can J Fish Aquat Sci 62:930-949. https://doi.org/10.1139/f04-246

Keefer ML, Peery CA, Heinrich MJ (2008a) Temperature-mediated migration mortality and travel rates of endangered Snake River sockeye salmon. Ecol Freshw Fish 17:136-145. https://doi.org/10.1111/j.1600-0633.2007. 00267.x

Keefer ML, Caudill CC, Peery CA, Lee SR (2008b) Transporting juvenile salmonids around dams impairs adult migration. Ecol Appl 18(8):1888-1900. https://doi.org/10. 1890/07-0710.1

Keefer ML, Taylor GA, Garlets DF, Pierce TM, Caudill CC (2010) Prespawn mortality in adult spring Chinook salmon outplanted above barrier dams. Ecol Freshw Fish 19:361-372. https://doi.org/10.1111/j.1600-0633.2010. 00418.x

Keefer ML, Taylor GA, Garletts DF, Helms CK, Gauthier GA, Pierce TM, Caudill CC (2012) Reservoir entrapment and dam passage mortality of juvenile Chinook salmon in the Middle Fork Willamette River. Ecol Freshw Fish 21:222-234. https://doi.org/10.1111/j.1600-0633.2011. 00540.x

Keefer ML, Taylor GA, Garletts DF, Helms CK, Gauthier GA, Pierce TM, Caudill CC (2013) High-head dams affect downstream fish passage timing and survival in the Middle Fork Willamette River. River Res Appl 29:483-492. https://doi.org/10.1002/rra.1613

Kelsey DA, Schreck CB, Congleton JL, Davis LE (2002) Effects of juvenile steelhead on juvenile Chinook salmon behavior and physiology. Effects of juvenile steelhead on juvenile Chinook salmon behavior and physiology. Trans Am Fish Soc 131:676-689. https://doi.org/10.1577/15488659(2002)131\%3c0676:EOJSOJ\%3e2.0.CO;2

Kock TJ, Evans SD, Rondorf DW (2009) Evaluation of strobe lights to reduce turbine entrainment of juvenile steelhead (Oncorhynchus mykiss) at Cowlitz Falls Dam, Washington. Northwest Sci 83:308-314. https://doi.org/10.3955/046. 083.0402

Kock TJ, Beeman JW, Hansen AC, Hansel HC, Hansen GS, Hatton TW, Kofoot EE, Sholtis MD, Sprando JM (2015) Behavior, passage and downstream migration of juvenile Chinook salmon from Detroit Reservoir to Portland, Oregon, 2014-2015. U.S. Geological Survey Open File Report 2015-1220. https://doi.org/10.3133/ofr20151220

Kock TJ, Ekstrom BK, Liedtke TL, Serl JD, Kohn M (2016) Behavior patterns and fates of adult steelhead, Chinook salmon, and coho salmon released into the upper Cowlitz River Basin, Washington, 2005-09 and 2012: U.S. Geological Survey Open-File Report 2016-1144. https://doi. org/10.3133/ofr20161144
Kock TJ, Evans SD, Hansen AC, Perry RW, Hansel HC, Haner PV, Tomka RG (2018a) Evaluation of sockeye salmon after passage through and innovative upstream fish-passage system at Cle Elum Dam, Washington, 2017. U.S. Geological Survey Open-File Report 2018-1116. https://doi. org/10.3133/ofr20181116

Kock TJ, Perry RW, Pope AC, Serl JD, Kohn M, Liedtke TL (2018b) Responses of hatchery- and natural-origin adult spring Chinook salmon to a trap-and-haul reintroduction program. N Am J Fish Manag 38:1004-1016. https://doi. org/10.1002/nafm.10199

Kock TJ, Verretto NE, Ackerman NK, Perry RW, Beeman JW, Garello MD, Fielding SD (2019a) Assessment of operational and structural factors influencing performance of fish collectors in forebays of high-head dams. Trans Am Fish Soc 148:464-479. https://doi.org/10.1002/tafs.10146

Kock TJ, Perry RW, Hansen GS, Haner PV, Pope AC, Plumb JM, Cogliati KM, Hansen, AC (2019b) Evaluation of Chinook salmon (Oncorhynchus tshawytscha) fry survival at Lookout Point Reservoir, western Oregon, 2017: U.S. Geological Survey Open-File Report 2019-1011. https:// doi.org/10.3133/ofr20191011.

Kozfkay C, Kiefer R, Baker D, Johnson E, Brown T (2017) Trap and haul emergency procedures and feasibility plan at Lower Granite Dam. Report by the Idaho Department of Fish and Game, Boise, Idaho, 17 pp. https://pweb.crohms. org/tmt/022217_Emergency_Trap_and_Haul_Plan_ FINAL.PDF. Accessed 3 Apr 2020

Kozfkay CC, Peterson M, Sandford BP, Johnson EL, Kline P (2019) The productivity and viability of Snake River sockeye salmon hatchery adults released into Redfish Lake, Idaho. Trans Am Fish Soc 148:308-323

Larinier M (2008) Fish passage experience at small-scale hydroelectric power plants in France. Hydrobiologia 609:97-108. https://doi.org/10.1007/s10750-008-9398-9

Liedtke TL, Kock TJ, Ekstrom BK, Royer IM, Rondorf DW (2010) Juvenile salmonid collection efforts in the upper Cowlitz River basin: 2009 evaluations, final report. Tacoma Power Report Series, Number 2010-01, Tacoma, Washington. https://doi.org/10.3133/70179290

Liedtke TL, Kock TJ, Rondorf DW (2013) Evaluation of the behavior and movement patterns of adult coho salmon and steelhead in the North Fork Toutle River, Washington, 2005-2009: U.S. Geological Survey Open-File Report 2013-1290. https://doi.org/10.3133/ofr20131290

Liermann M, Pess G, McHenry M, McMillan J, Elofson M, Bennett T, Moses R (2017) Relocation and recolonization of coho salmon in two tributaries of the Elwha River: implications for management and monitoring. Trans Am Fish Soc 146:955-966. https://doi.org/10.1080/00028487. 2017.1317664

Loch J, Downing P (1990) 1989 Toutle River fish collection facility operation and salmonid investigations. Report by the Washington Department of Fish and Wildlife, Olympia, Washington. https://docs.streamnetlibrary.org/ StreamNet_References/WAsn613.pdf. Accessed 25 Apr 2020

Lusardi RA, Moyle PB (2017) Two-way trap-and-haul as a conservation strategy for anadromous salmonids. Fisheries 42:478-487. https://doi.org/10.1080/03632415.2017. 1356124 
Major JJ, Pierson TC, Dinehart RL, Costa JE (2000) Sediment yield following severe volcanic disturbance-a two-decade perspective from Mount St. Helens. Geology 28(9):819-822. https://doi.org/10.1130/0091-7613(2000) 28\%3c819:SYFSVD\%3e2.0.CO;2

Mantua N, Tohver I, Hamlet A (2010) Climate change impacts on streamflow extremes and summertime stream temperature and their possible consequences for freshwater salmon habitat in Washington State. Clim Change 102:187-223. https://doi.org/10.1007/s10584-010-9845-2

Mapes RL, Sharpe CS, Friesen TA (2017) Evaluation of the trap and transport of adult steelhead above USACE project dams in the upper Willamette basin. Report by the Oregon Department of Fish and Wildlife to the U.S. Army Corps of Engineers, Portland, Oregon. https://nrimp.dfw.state.or.us/ web\%20stores/data\%20libraries/files/ODFW/ODFW_ 1213_2_WillametteSteelheadEvaluationTrapAndTransport 2017.pdf. Accessed 3 Apr 2020

Matala AP, Narum SR, Saluskin BP, Johnston MV, Newell JE, Fast DE, Galbreath PF (2019) Early observations from monitoring a reintroduction program: return of sockeye salmon to a nursery lake of historical importance. Trans Am Fish Soc 148:271-288. https://doi.org/10.1002/tafs. 10133

Maule AG, Schreck CB, Bradford CS, Barton BA (1988) Physiological effects of collecting and transporting emigrating juvenile Chinook past dams on the Columbia River. Trans Am Fish Soc 117:245-261. https://doi.org/10.1577/ 1548-8659(1988)117\%3c0245:PEOCAT\%3e2.3.CO;2

Mazic PM, Simco BA, Parker NC (1991) Influence of water hardness and salts on survival and physiological characteristics of striped bass during and after transport. Trans Am Fish Soc 120:121-126. https://doi.org/10.1577/15488659(1991)120\%3c0121:IOWHAS\%3e2.3.CO;2

McClure MM, Holmes EE, Sanderson BL, Jordan CE (2003) A large-scale, multispecies status assessment: anadromous salmonids in the Columbia River basin. Ecol Appl 13(4):964-989

McCutcheon CS, Prentice EF, Park DL (1994) Passive monitoring of migrating adult steelhead with PIT tags. N Am J Fish Manag 14:220-223. https://doi.org/10.1577/15488675(1994)014\%3c0220:PMOMAS\%3e2.3.CO;2

McElhany P, Ruckelshaus MH, Ford MF, Wainwright TC, Bjorkstedt EP (2000) Viable salmonid populations and the recovery of evolutionarily significant units. Northwest Fisheries Science Center, NOAA Fisheries, Seattle

McHenry M, McMillan J, Moses R, Pess G (2018) Coho salmon relocations and redd surveys in the Elwha River 2011-2017: summary report. Report by the Lower Elwha Klallam Tribe to the Olympic National Park. https:// faculty.wwu.edu/ jmcl/Field_camp/elwha_ bibliography_42019.pdf. Accessed 30 Apr 2020

McMichael GA, Skalski JR, Deters KA (2011) Survival of juvenile Chinook salmon during barge transport. N Am J Fish Manag 31:1187-1196. https://doi.org/10.1080/ 02755947.2011.646455

Mesa MG, Gee LP, Weiland LK, Christiansen HK (2013) Physiological responses of adult rainbow trout experimentally released through a unique fish conveyance device. N Am J Fish Manag 33:1179-1183. https://doi.org/10. $1080 / 02755947.2013 .833560$
Monzyk FR, Emig R, Romer JD, Friesen TA (2015a) Life-history characteristics of juvenile spring Chinook salmon rearing in Willamette Valley reservoir. Report by the Oregon Department of Fish and Wildlife to the U.S. Army Corps of Engineers, Portland, Oregon. https://odfw. forestry.oregonstate.edu/willamettesalmonidrme/sites/ default/files/outmigration_monitoring_annual_2016_final. pdf. Accessed 3 Apr 2020

Monzyk FR, Friesen TA, Romer JD (2015b) Infection of juvenile salmonids by Salmincola californiensis (Copepoda: Lernaeopodidae) in reservoir and streams of the Willamette River Basin, Oregon. Trans Am Fish Soc 144:891-902. https://doi.org/10.1080/00028487.2015. 1052558

Morrisett CN, Skalski JR, Kiefer RB (2018) Passage route and upstream migration success: a case study of Snake River salmonids accessing Lower Granite Dam. N Am J Fish Manag 39:58-68. https://doi.org/10.1002/nafm.10245

Moyle PB, Cech JJ (1988) Fishes: an introduction to ichthyology. Prentice Hall, Englewood Cliffs

Muir WD, Smith SG, Williams JG, Sandford BP (2001) Survival of juvenile salmonids passing through bypass systems, turbines, and spillways with and without flow detectors at Snake River Dams. N Am J Fish Manag 21:135-146. https://doi.org/10.1577/1548-8675(2001) 021\%3c0135:SOJSPT\%3e2.0.CO;2

Muir WD, Marsh DM, Sandford BP, Smith SG, Williams JG (2006) Post-hydropower system delayed mortality of transported Snake River stream-type Chinook salmon: unraveling the mystery. Trans Am Fish Soc 135:1523-1534. https://doi.org/10.1577/T06-049.1

Murauskas JG, Fryer JK, Nordlund B, Miller JL (2014) Trapping effects and fisheries research: a case study of sockeye salmon in the Wenatchee River, USA. Fisheries 39: 408-414. https://doi.org/10.1080/03632415.2014.943366

Murphy CA, Arismendi I, Taylor GA, Johnson SL (2019) Evidence for lasting alterations to aquatic food webs with short-duration reservoir draining. PLoS ONE 14(2): e0211870. https://doi.org/10.1371/journal.pone.0211870

Myers J (2017) Assessment of reintroduction strategies and monitoring of Chinook salmon and steelhead populations in the upper Willamette River. Report from the Northwest Fisheries Science Center to the U.S. Army Corps of Engineers, Portland District

Naish KA, Taylor JE, Levin PS, Quinn TP, Winton JR, Huppert D, Hilborn R (2008) An evaluation of the effects of conservation and fishery enhancement hatcheries on wild populations of salmon. Adv Mar Biol 53:61-194. https:// doi.org/10.1016/S0065-2881(07)53002-6

Naughton GP, Caudill CC, Keefer ML, Bjornn TC, Peery CA, Stuehrenberg LC (2006) Fallback by adult sockeye salmon at Columbia River dams. N Am J Fish Manag 26:380-390. https://doi.org/10.1577/M05-015.1

Naughton GP, Keefer ML, Clabough TS, Knoff MJ, Blubaugh TJ, Sharpe C, Caudill CC (2018) Reservoir provides coolwater refuge for adult Chinook salmon in a trap-and-haul reintroduction program. Mar Freshw Res 69(12):19952007. https://doi.org/10.1071/MF18124

Nehlsen W, Williams JE, Lichatowich JA (1991) Pacific salmon at the crossroads: stocks at risk from California, Oregon, Idaho, and Washington. Fisheries 16(2):4-21 
Nestler JM, Goodwin RA, Smith DL, Anderson JJ, Li S (2008) Optimum fish passage and guidance designs are based in the hydrogeomorphology of natural rivers. River Res Appl 24:148-168. https://doi.org/10.1002/rra.1056

Nicola GG, Elvira B, Almodovar A (1996) Dams and fish passage facilities in the large rivers of Spain: effects on migratory species. Larg Rivers 10:375-379

NMFS (National Marine Fisheries Service) (1991) Endangered and threatened species; endangered status for Snake River Sockeye Salmon. Federal Register 56:224(November 20, 1991):58619-58624. https://www.govinfo.gov/content/ pkg/FR-1991-11-20/pdf/FR-1991-11-20.pdf. Accessed 17 Apr 2020

NMFS (National Marine Fisheries Service) (2008) Endangered species act section 7(a)(2) consultation biological opinion and Magnuson-Stevens fishery conservation and management act essential fish habitat consultation: consultation on the "Willamette River basin flood control project." NMFS, Northwest Region, Seattle. https://www.westcoast. fisheries.noaa.gov/fishpassage/willametteopinion/. Accessed 3 Apr 2020

NMFS (National Marine Fisheries Service) (2011) Anadromous salmonid passage facility design. NMFS, Northwest Region, Portland, Oregon. https://www.westcoast. fisheries.noaa.gov/publications/hydropower/fish_passage_ design_criteria.pdf. Accessed 16 June 2019

NMFS (National Marine Fisheries Service) (2014) Recovery plan for the evolutionarily significant units of sacramento river winter-run chinook salmon and central valley springrun chinook salmon and the distinct population segment of California Central Valley Steelhead. California Central Valley Area Office

NOAA (National Oceanic and Atmospheric Administration) (2014) Endangered Species Act Section 7 (a)(2) Supplemental biological opinion, consultation on remand for operation of the Federal Columbia River Power System. NOAA Fisheries, Portland, Oregon. https://www.fisheries. noaa.gov/resource/document/consultation-remandoperation-federal-columbia-river-power-system. Accessed 6 Apr 2020

NOAA (National Oceanic and Atmospheric Administration) (2015) 2015 Adult sockeye salmon passage report. Report by NOAA Fisheries, the U.S. Army Corps of Engineers, and Idaho Department of Fish and Game. https://archive. fisheries.noaa.gov/wcr/publications/hydropower/fcrps/ 2015_adult_sockeye_salmon_passage_report.pdf. Accessed 6 Apr 2020

Noonan MJ, Grant JWA, Jackson CD (2012) A quantitative assessment of fish passage efficiency. Fish Fish 13:450-464. https://doi.org/10.1111/j.1467-2979.2011. 00445. $\mathrm{x}$

Normandeau Associates, Inc. (2010) Estimates of direct survival and injury of juvenile rainbow trout (Oncorhynchus mykiss) passing spillway, turbine, and regulating outlet at Detroit Dam, Oregon. Report to the U.S. Army Corps of Engineers, Portland, Oregon

Northwest Fisheries Science Center (2015) Status review update for Pacific salmon and steelhead listed under the Endangered Species Act: Pacific Northwest. https://www.nwfsc. noaa.gov/assets/11/8623_03072016_124156_Ford-
NWSalmonBioStatusReviewUpdate-Dec\%2021-2015\%

20v2.pdf. Accessed 6 Apr 2020

Ogut H, LaPatra SE, Reno PW (2005) Effects of host density on furunculosis epidemics determined by the simple SIR model. Prev Vet Med 71(1-2):83-90. https://doi.org/10. 1016/j.prevetmed.2005.06.001

Ohlberger J, Ward EJ, Schindler DE, Lewis B (2018) Demographic changes in Chinook salmon across the Northeast Pacific Ocean. Fish Fish 19(3):533-546. https://doi.org/10. 1111/faf.12272

PacifiCorp (2018) Lewis River fish passage program 2017 annual report. Report by PacifiCorp and Public Utility District No. 1 of Cowlitz County for FERC project numbers 935, 2071, 2111, and 2213. https://www.pacificorp. com/content/dam/pcorp/documents/en/pacificorp/energy/ hydro/lewis-river/license-implementation/reports/LR 2017_ACC_TCC_AR_web.pdf. Accessed 3 Apr 2020

PacifiCorp (2019) Lewis River fish passage program 2018 annual report. Report by PacifiCorp and Public Utility District No. 1 of Cowlitz County for FERC project numbers 935, 2071, 2111, and 2213. https://www.pacificorp. com/content/dam/pcorp/documents/en/pacificorp/energy/ hydro/lewis-river/license-implementation/reports/ 04122019_LR_2018_ACC_TCC_AR_web.pdf. Accessed 3 Apr 2020

Perry RW, Romine JG, Adams NS, Blake AR, Burau JR, Johnston SV, Liedtke TL (2014) Using a non-physical behavioral barrier to alter migration routing of juvenile Chinook salmon in the Sacramento-San Joaquin river delta. River Res Appl 30:192-203. https://doi.org/10.1002/rra. 2628

Pess GR (2009) Patterns and processes of salmon colonization. Doctoral dissertation. University of Washington, Seattle. https://faculty.washington.edu/tquinn/pubs/pess_thesis 2009.pdf. Accessed 3 Apr 2020

Poe TP, Hansel HC, Vigg S, Palmer DE, Prendergast LA (1991) Feeding of predaceous fishes on out-migrating juvenile salmonids in John Day Reservoir, Columbia River. Trans Am Fish Soc 120:405-420. https://doi.org/10.1577/15488659(1991)120\%3c0405:FOPFOO\%3e2.3.CO;2

Pompeu PS, Agostinho AA, Pelicice FM (2012) Existing and future challenges: the concept of successful fish passage in South America. River Res Appl 28:504-512. https://doi. org/10.1002/rra.1557

PGE (Portland General Electric). 2018. Pelton Round Butte Project (FERC No. 2030) 2017 fish passage annual report. Submitted to the Federal Energy Regulatory Commission, Washington D.C. Project 2030. https://elibrary.ferc.gov/ idmws/common/OpenNat.asp?fileID=14925984. Accessed 17 Apr 2020

Pracheil BM, DeRolph CR, Schramm MP, Bevelhimer MS (2016) A fish-eye view of riverine hydropower systems: the current understanding of the biological response to turbine passage. Rev Fish Biol Fish. https://doi.org/10.1007/ s11160-015-9416-8

Quinn TP (2005) The behavior and ecology of Pacific salmon and trout. University of Washington Press, Seattle, Washington. https://doi.org/10.1086/503983

Quinn TP, Eggers DM, Clark JH, Rich HB (2007) Density, climate, and the processes of prespawning mortality and egg retention in Pacific salmon (Oncorhynchus spp.). Can J 
Fish Aquat Sci 64:574-582. https://doi.org/10.1139/f07035

Rechisky EL, Welch DW, Porter AD, Hess JE, Narum SR (2014) Testing for delayed mortality effects in the early marine life history of Columbia River Basin yearling Chinook salmon. Mar Ecol Prog Sect 496:159-180. https:// doi.org/10.3354/meps10692

Reischel TS, Bjornn TC (2003) Influence of fishway placement on fallback of adult salmon at the Bonneville Dam on the Columbia River. N Am J Fish Manag 23:1215-1224. https://doi.org/10.1577/M02-113

Richins SM, Skalski JR (2018) Steelhead overshoot and fallback rates in the Columbia-Snake River basin and the influence of hatchery and hydrosystem operations. N Am J Fish Manag 38:1122-1137. https://doi.org/10.1002/nafm. 10219

Rieman BE, Beamesderfer RC, Vigg S, Poe TP (1991) Estimated loss of juvenile salmonids to predation by northern squawfish, walleyes, and smallmouth bass in John Day reservoir, Columbia River. Trans Am Fish Soc 120:448-458. https://doi.org/10.1577/15488659(1991)120\%3c0448:ELOJST\%3e2.3.CO;2

Romer JD, Monzyk FR, Emig R, Friesen TA (2016) Juvenile salmonid outmigration monitoring at Willamette Valley project reservoirs. Report by the Oregon Department of Fish and Wildlife for the U.S. Army Corps of Engineers, Portland District, Portland, Oregon. https://odfw.forestry. oregonstate.edu/willamettesalmonidrme/sites/default/ files/outmigration_monitoring_annual_2016_final.pdf. Accessed 3 Apr 2020

Roscoe DW, Hinch SG (2010) Effectiveness monitoring of fish passage facilities; historical trends, geographic patterns and future decisions. Fish Fish 11:12-23. https://doi.org/ 10.1111/j.1467-2979.2009.00333.x

Sard NM, O’Malley KG, Jacobson DP, Hogansen MJ, Johnson MA, Banks MA (2015) Factors influencing spawner success in a spring Chinook salmon (Onchorhynchus tshawytscha) reintroduction program. Can J Fish Aquat Sci 72:1390-1397. https://doi.org/10.1139/cjfas-2015-0007

Sard NM, Johnson MA, Jacobson DP, Hogansen MJ, O'Malley KG, Banks MA (2016) Genetic monitoring guides adaptive management of a migratory fish reintroduction program. Anim Conserv 19:570-577. https://doi.org/10.1111/acv. 12278

Satterthwaite WH, Carlson SM, Allen-Moran SD, Vincenzi S, Bograd SJ, Wells BK (2014) Match-mismatch dynamics and the relationships between ocean-entry timing and relative ocean recoveries of Central Valley fall run Chinook salmon. Mar Ecol Prog Ser 511:237-248. https://doi.org/ 10.3354/meps 10934

Scheel D, Hough KR (1997) Salmon fry predation by seabirds near an Alaskan hatchery. Mar Ecol Prog Ser 150:35-48. https://doi.org/10.3354/meps150035

Scheuerell MD, Zabel RW, Sandford BP (2009) Relating juvenile migration timing and survival to adulthood in two species of threatened Pacific salmon (Oncorhynchus spp.). J Appl Ecol 46:983-990. https://doi.org/10.1111/j.13652664.2009.01693.x

Schilt CR (2007) Developing fish passage and protection at hydropower dams. Appl Anim Behav Sci 104:295-325. https://doi.org/10.1016/j.applanim.2006.09.004
Schreck CB (1980) Effects of transportation on fitness for marine survival of Columbia River salmon. National Marine Fisheries Service Completion Report. https://ir. library.oregonstate.edu/concern/technical_reports/ ks65hk619

Schreck CB, Li HW (1985) Columbia River salmonid outmigration: McNary Dam passage and enhanced smolt quality: U.S. Army Corps of Engineers. https://ir.library. oregonstate.edu/concern/technical_reports/br86b955p

Schreck CB, Tort L (2016) The concept of stress in fish. In: Schreck CB, Tort L, Farrell A, Brauner C (eds) Biology of stress in fish. Elsevier, London, pp 1-34. https://doi.org/10. 1016/B978-0-12-802728-8.00001-1

Schreck CB, Solazzi MF, Johnson SL, Nickelson TE (1989) Transportation stress affects performance of coho salmon, Oncorhynchus kisutch. Aquaculture 82:15-20

Schreck CB, Jonsson L, Feist G, Reno P (1995) Conditioning improves performance of juvenile Chinook salmon, Oncorhynchus tshawytscha, to transportation stress. Aquaculture 135:99-110. https://doi.org/10.1016/00448486(95)01018-1

Schreck CB, Olla BL, Davis MW (1997) Behavioral responses to stress. In: Iwama GW, Sumpter J, Pickering AD, Schreck CB (eds) Fish stress and health in aquaculture. Cambridge University Press, Cambridge, pp 745-770

Schreck CB, Stahl TP, Davis LE, Roby DD, Clemens BJ (2006) Mortality estimates of juvenile spring-summer Chinook salmon in the lower Columbia River and estuary, 1992-198: evidence for delayed mortality? Trans Am Fish Soc 135:457-475. https://doi.org/10.1577/T05-184.1

Schroeder RK, Whitman LD, Cannon B, Olmsted P (2016) Juvenile life-history diversity and population stability of spring Chinook salmon in the Willamette River basin, Oregon. Can J Fish Aquat Sci 73:921-934. https://doi.org/ 10.1139/cjfas-2015-0314

Schtickzelle N, Quinn TP (2007) A metapopulation perspective for salmon and other anadromous fish. Fish Fish 8:297-314. https://doi.org/10.1111/j.1467-2979.2007. 00256.x

Scruton DA, McKinley RS, Kouwen N, Eddy W, Booth RK (2003) Improvement and optimization of fish guidance efficiency at a behavioral fish protection system for downstream migrating Atlantic salmon (Salmo salar) smolts. River Res Appl 19:605-617. https://doi.org/10. 1002/rra.735

Shanley CS, Albert DM (2014) Climate change sensitivity index for Pacific salmon habitat in southeast Alaska. PLoS ONE 9(11):e112926. https://doi.org/10.1371/journal.pone.0104 799

Sharpe CS, Cannon B, DeBow B, Friesen TA, Hewlett D, Olmsted P, Sinnott M (2016) Work completed for compliance with the 2008 Willamette Project Biological Opinion, USACE funding: 2014 hatchery baseline monitoring. Report by the Oregon Department of Fish and Wildlife to the U.S. Army Corps of Engineers, Portland, Oregon. https:// odfw.forestry.oregonstate.edu/willamettesalmonidrme/ hatchery-publications. Accessed 30 Apr 2020

Shi X, Kynard B, Liu D, Qiao Y, Chen Q (2015) Development of fish passage in China. Fisheries 40:161-169. https://doi. org/10.1080/03632415.2015.1017634 
Shively RS, Poe TP, Sheer MB (1996) Criteria for reducing predation by northern squawfish near juvenile salmonid bypass outfalls at Columbia River dams. Regul Rivers Res Manag 12:493-500. https://doi.org/10.1002/(SICI)10991646(199607)12:4/5\%3c493::AID-RRR411\%3e3.0. $\mathrm{CO} ; 2-\mathrm{C}$

Sigourney DB, Zydlewski JD, Hughes E, Cox O (2015) Transport, dam passage, and size selection of adult Atlantic salmon in the Penobscot River, Maine. N Am J Fish Manag 35:1164-1176. https://doi.org/10.1080/02755947.2015. 1099578

Skalski JR, Townsend R, Lady J, Giorgi AE, Stevenson JR, McDonald RD (2002) Estimating route-specific passage and survival probabilities at a hydroelectric project from smolt studies. Can J Fish Aquat Sci 59:1385-1393. https:// doi.org/10.1080/02755947.2016.1165775

Skalski JR, Weiland MA, Ham KD, Ploskey GR, McMichael GA, Colotelo AH, Carlson TJ, Woodley CM, Eppard BM, Hockersmith EE (2016) Status after 5 years of survival compliance testing in the federal Columbia river power system (FCRPS). N Am J Fish Manag 36:720-730. https:// doi.org/10.1080/02755947.2016.1165775

Specker JL, Schreck CB (1980) Stress responses to transportation and fitness for marine survival in coho salmon (Oncorhynchus kisutch) smolts. Can J Fish Aquat Sci 37:765-769. https://doi.org/10.1139/f80-102

Stewart HA, Cogliati KM, Billman EJK, Unrein JR, Noakes DLG, Schreck CB (2017) Effects of transportation timing on osmoregulation and survival in yearling hatchery Chinook salmon (Oncorhynchus tshawytscha). J Appl Aquac 29:277-290. https://doi.org/10.1080/10454438.2017. 1372839

Sweeney CE, Hall R, Giorgi AE, Miller M, Johnson GE (2007) Surface bypass program comprehensive review report. ENSR, document number 09000-399-0409, Redmond, Washington. https://usace.contentdm.oclc.org/digital/ collection/p16021 coll3/id/508/. Accessed 6 Apr 2020

Tacoma Power (2016a) Cushman hydroelectric project, FERC no. 460 license article 416 downstream fish passage report: 2015 annual report. Report by Tacoma Power to the Federal Energy Regulatory Commission

Tacoma Power (2016b) Cushman hydroelectric project, FERC no. 460 license articles 415 and 416 upstream fish passage: 2015 annual report. Report by Tacoma Power to the Federal Energy Regulatory Commission

Tacoma Power (2017) Cushman hydroelectric project, FERC no. 460 license article 416 downstream fish passage report: 2016 annual report. Report by Tacoma Power to the Federal Energy Regulatory Commission

Tiffan KF, Rondorf DW, Wagner PG (2000) Physiological development and migratory behavior of subyearling fall Chinook salmon in the Columbia River. N Am J Fish Manag 20:28-40. https://doi.org/10.1577/15488675(2000)020\%3c0028:PDAMBO\%3e2.0.CO;2

Tiffan KF, Kock TJ, Connor WP, Mullins F, Steinhorst RK (2012) Downstream movement of fall Chinook salmon juveniles in the lower Snake River reservoirs during winter and early spring. Trans Am Fish Soc 141:285-293. https:// doi.org/10.1080/00028487.2012.662203

Thompson TQ, Bellinger MR, O'Rourke SM, Prince DJ, Stevenson AE, Rodrigues AT, Sloat MR, Speller CF, Yang
DY, Butler VL, Banks MA, Miller MR (2019) Anthropogenic habitat alteration leads to rapid loss of adaptive variation and restoration potential in wild salmon populations. Proc Natl Acad Sci 116:177-186. https://doi.org/10. 1073/pnas.1811559115

Trammell JLJ, Fast DE, Hatch DR, Bosch WJ, Branstetter R, Pierce AL, Blodgett JW, Frederiksen C (2016) Evaluating steelhead kelt treatments to increase iteroparous spawners in the Yakima River Basin. N Am J Fish Manag 36:876-887. https://doi.org/10.1080/02755947.2016. 1165767

UCUT (Upper Columbia United Tribes) (2019) Fish passage and reintroduction phase 1 report: investigations upstream of Chief Joseph and Grand Coulee Dams. Report by the Upper Columbia United Tribes. https://ucut.org/habitat/ fish-passage-and-reintroduction-phase-1-report/. Accessed 1 Apr 2020

U.S. Army Corps of Engineers (USACE) (2018) Cougar Dam downstream fish passage. Design documentation report number 24. Report by the U.S. Army Corps of Engineers, Portland District, Portland, Oregon. https://pweb.crohms. org/tmt/documents/FPOM/2010/Willamette_Coordination/ Willamette\%20FPT/2018_November/Cougar\%20Downstream \%20Passage\%2090\%20DDR\%2011-1-18.pdf. Accessed 6 Apr 2020

Van Gaest AL, Dietrich JP, Thompson DE, Boylen DA, Strickland SA, Collier TK, Loge FJ, Arkoosh MR (2011) Survey of pathogens in hatchery Chinook salmon with different out-migration histories through the Snake and Columbia rivers. J Aquat Anim Health 23:62-77. https:// doi.org/10.1080/00028487.2011.572023

Venditti DA, Rondorf DW, Kraut JM (2000) Migratory behavior and forebay delay of radio-tagged juvenile fall Chinook salmon in a lower Snake River impoundment. N Am J Fish Manag 20:41-52. https://doi.org/10.1577/ 1548-8675(2000)020\%3c0041:MBAFDO\%3e2.0.CO;2

Voigt B, Glicken H, Janda RJ, Douglas PM (1981) Catastrophic rockslide avalanche of May 18. In: Lipman, P.W., and Mullineaux, D.R., (eds) The 1980 eruptions of Mount St. Helens, Washington: U.S. Geological Survey Professional Paper 1250. https://pubs.er.usgs.gov/publication/pp1250

Waples RS, Johnson OW, Jones RP (1991) Status review for Snake River Sockeye Salmon. NOAA Technical Memorandum NMFS-F/NWC-195. https://repository. library.noaa.gov/view/noaa/21168. Accessed 6 Apr 2020

Ward BR, Slaney PA (1993) Egg-to-smolt survival and fry-tosmolt density dependence of Keogh River steelhead trout. In: Gibson RJ, Cutting RE (eds) Production of juvenile Atlantic salmon, Salmo salar, in natural waters. Canadian Special Publication Fisheries and Aquatic Sciences 118, pp 209-217. https://doi.org/10.1139/9780660149547

Ward DL, Boyce RR, Young FR, Olney FE (1997) A review and assessment of transportation studies for juvenile Chinook salmon in the Snake River. N Am J Fish Manag 17:652-662. https://doi.org/10.1577/1548-8675(1997)017\% 3c0652:ARAAOT\%3e2.3.CO;2

Wedemeyer GA (1976) Physiological response of juvenile coho salmon (Oncorhynchus kisutch) and rainbow trout (Salmo gairdneri) to handling and crowding stress in intensive fish culture. J Fish Res Board Can 33:2699-2702. https://doi. org/10.1139/f76-320 
Weigel DI, Koch F, Monzyk F, Sharpe C, Narum S, Caudill CC (2019) Evaluation of a trap-and-haul program for a threatened population of steelhead (Oncorhynchus mykiss). Conserv Genet 20:1195-1199. https://doi.org/10.1007/ s10592-019-01200-5

Weitkamp LA, Teel DJ, Liermann M, Hinton SA, Van Doornik DM, Bentley PJ (2015) Stock-specific size and timing at ocean entry of Columbia River juvenile Chinook salmon and steelhead: implications for early ocean growth. Mar Coast Fish Dyn Manag Ecosyst Sci 7:370-392. https://doi. org/10.1080/19425120.2015.1047476
Williams JG, Armstrong G, Katopodis C, Larinier M, Travade F (2012) Thinking like a fish: a key ingredient for development of effective fish passage facilities at river obstructions. River Res Appl 28:407-417. https://doi.org/10.1002/ rra. 1551

Publisher's Note Springer Nature remains neutral with regard to jurisdictional claims in published maps and institutional affiliations. 